\title{
Origin of Pumice in Sediments from the Middle Okinawa Trough: Constraints from Whole-Rock Geochemical Compositions and $\mathrm{Sr}-\mathrm{Nd}-\mathrm{Pb}$ Isotopes
}

\author{
Xue Fang ${ }^{1,2}$, Zhigang Zeng ${ }^{1,2,3,4, *}$, Siyi Hu ${ }^{1,2}$, Xiaohui Li ${ }^{1}{ }^{1}$, Zuxing Chen ${ }^{1}$, Shuai Chen ${ }^{1}$ and \\ Bowen Zhu ${ }^{1,2}$ (D) \\ 1 Seafloor Hydrothermal Activity Laboratory, CAS Key Laboratory of Marine Geology and Environment, \\ Institute of Oceanology, Chinese Academy of Sciences, Qingdao 266071, China; fxue13@163.com (X.F.); \\ niudun2901@163.com (S.H.); xiaohuili0526@foxmail.com (X.L.); chenzuxing14@mails.ucas.ac.cn (Z.C.); \\ chenshuai@qdio.ac.cn (S.C.); zhubowen16@mails.ucas.ac.cn (B.Z.) \\ 2 College of Earth and Planetary Sciences, University of Chinese Academy of Sciences, Beijing 100049, China \\ 3 Laboratory for Marine Mineral Resources, Qingdao National Laboratory for Marine Science and Technology, \\ Qingdao 266071, China \\ 4 Center for Ocean Mega-Science, Chinese Academy of Sciences, 7 Nanhai Road, Qingdao 266071, China \\ * Correspondence: zgzeng@ms.qdio.ac.cn
}

Received: 16 October 2019; Accepted: 7 November 2019; Published: 16 December 2019

\begin{abstract}
Frequent volcanic activity has occurred in the Okinawa Trough (OT) during the late Quaternary, which attracted much attention to the origin of volcanic rocks. Pumice collected from the seafloor has been extensively investigated, whereas few studies paid attention to the pumice in the sediment. The geochemical compositions of pumice preserved in sediments generally provide insight into past volcanic activity and regional magmatism. Here, we present major and trace element compositions and $\mathrm{Sr}-\mathrm{Nd}-\mathrm{Pb}$ isotope data, together with the established age framework for pumice samples recovered from sediment core S9 in the middle OT (MOT) to investigate their possible formation. Compositionally, the S9 pumice samples are dacite and are characterized by relatively higher $\mathrm{Sr}\left({ }^{87} \mathrm{Sr} /{ }^{86} \mathrm{Sr}=0.70480-0.70502\right)$ and $\mathrm{Pb}\left({ }^{206} \mathrm{~Pb} /{ }^{204} \mathrm{~Pb}=18.321-18.436,{ }^{207} \mathrm{~Pb} /{ }^{204} \mathrm{~Pb}=\right.$ $15.622-15.624$, and $\left.{ }^{208} \mathrm{~Pb} /{ }^{204} \mathrm{~Pb}=38.52-38.63\right)$ and lower $\mathrm{Nd}\left({ }^{143} \mathrm{Nd} /{ }^{144} \mathrm{Nd}=0.51272-0.51274\right)$ isotope compositions than basalts from the MOT. The geochemical compositions of pumice clasts from different layers of core S9 display no temporal variation trends and vary within narrow ranges. On the basis of the geochemical characteristics of S9 pumice samples, we infer that the parent magma of these samples might generate from hybrid magma through an extensive fractional crystallization process. The Indian Ocean MORB-type mantle was first metasomatized by the subducted Philippine Sea sediments to form the primitive magma; then, followed by assimilation of a small amount of lower crustal component occurred in the lower crust. The long-term magmatism and relatively consistent isotopic compositions indicate that a magma chamber might have existed in the lower crust of the MOT between 11.22 and $12.96 \mathrm{cal}$. ka BP.
\end{abstract}

Keywords: pumice in sediments; $\mathrm{Sr}-\mathrm{Nd}-\mathrm{Pb}$ isotope; hybrid magma; fractionation crystallization; origin of pumice; middle Okinawa Trough

\section{Introduction}

The subduction zone, as a crucial interface of material exchange between the Earth's crust and mantle, is one of the critical areas for plate subduction and consumption as well as for the generation of magmatism [1-3]. The back-arc basin is an essential part of trench-arc-basin subduction system. Achievements of the Ocean Drilling Program (ODP) have revealed that back-arc basins 
play an important role in the study of geodynamics and provide valuable information about the origin of mantle-derived magma, interactions between the crust and mantle, crustal accretion and oceanic-continental transitions [4-6]. In recent decades, the studies of back-arc basin magmatism have gained increased attention [7-9].

The Okinawa Trough (OT) located behind the Ryukyu arc-trench system is an active marginal sea basin that is still in the early stage of expansion [10-12]. Extensive volcanic activity has given rise to numerous volcanic rocks, making the OT an ideal area for studying the magmatism associated with back-arc basin initiation $[13,14]$. Volcanic rocks can provide information about magma evolution and geodynamic mechanisms in the OT [15]. Pumice is the most widely distributed volcanic rock in the OT $[16,17]$. Zhai [18] reported that pumice was mainly distributed in the central and northern part of the OT, which can be observed both on the seafloor and in sediment interlayers. The geochemical and mineralogical characteristics of pumice were used to investigate the source magma compositions [19-21], magmatic evolution [14], and implications for magma chambers [22] in the OT. The origin of pumice in the OT; however, remains to be clarified despite much research effort [19,23-25]. Most of the studies suggest that pumice were derived from basaltic magma through fractional crystallization [26,27], while a few studies suggest the partial remelting of andesites [23]. The divergence of these interpretations can be ascribed to the lack of an age framework and the poor recognition of pumice types.

The OT is characterized by complex magmatic and tectonic activity, and has different geological backgrounds in three sections divided by the Tokara Strait $\left(\sim 29.3^{\circ} \mathrm{N}\right)$ and the Kerama Gap $\left(\sim 26^{\circ} \mathrm{N}\right)[12,28,29]$. Due to the difficulties in dating young geological material $[7,10,25,30,31]$, a majority of studies fail to establish the age model when analyzing the magma sources and evolutions of volcanic rocks in the OT $[19,20,23]$. Because the magmatic components and tectonic conditions in the study area have likely changed in this rapidly developing region during different eruption times, the lack of age framework may result in problematic interpretation of the results. The volcanic material (e.g., pumice clasts) also contributed significantly to the sedimentation in the OT since the late Quaternary, which are well documented by previous studies [18,30,32]. Pumice in sediments can provide pumice samples beneath the seafloor for geochemical study, and their chronological framework can be established using radiocarbon dating. Nonetheless, previous studies were mainly focused on pumice that recovered from the surface of the seafloor with a television (TV) grab sampler or trawl sampler $[19,20,23]$, and few studies have focused on pumice recovered from marine sediments. We collected a sediment core from a slope setting in the middle OT (MOT) to investigate the origin of the pumice in sediment of the study area for the first time.

Here, we present the geochemical data and eruption age of pumice clasts in sediment core S9 from the MOT. The objectives of this study are (1) to characterize the geochemical compositions of the pumice, (2) to identify the potential magma sources of the pumice, and (3) to investigate the possible petrogenesis of the pumice in the sediment from the MOT.

\section{Geological Setting and Samples}

The OT is a newborn back-arc basin that is located in the eastern part of the East China Sea (ECS) and formed between the ECS shelf and the Ryukyu volcanic arc, which is related to the subduction of the Philippine Sea Plate beneath the Eurasian Plate (Figure 1) [33-35]. The total length of the OT is approximately $1300 \mathrm{~km}$; it starts from the Kyushu Island in the north and ends at Taiwan Province in the south $[8,12]$. The OT is characterized by a complex geological background with obviously thin crust compared with the ECS shelf and the Ryukyu arc and anomalously high heat flow and gravity values $[11,34,36]$. Generally, the OT can be divided into three segments by the Tokara Strait and the Kerama Gap: the northern OT (NOT), the MOT, and the southern OT (SOT) [37]. Magmatism in the OT is bimodal, showing dominantly basaltic and rhyolitic rocks with small amounts of intermediate volcanic rocks [11,38]. Pumice is widely distributed in the three segments of the OT, whereas basalts mainly occur in the middle and southern segments [26]. Although volcanic rocks are widespread in the OT, few studies have reported on the eruption age of volcanic rocks collected from the OT due to 
difficulties in dating young volcanic rocks $[7,17]$. According to previous studies, the earliest eruption age of volcanic rocks is approximately $4 \mathrm{Ma}$ [31], and most of the volcanic rocks collected from the OT are younger than $1 \mathrm{Ma}[25,30]$. Additionally, the OT is located in a semi-abyssal area and represents a transitional environment between the shelf sedimentary environment and the abyssal sedimentary environment [10]. The OT is covered by large quantities of semi-abyssal sediments [33,39], especially in the MOT with 2-3 km-thick sediment layers [40]. These sediments are mainly composed of terrigenous sediments from around large rivers, as well as abundant biodetritus and volcanic material [32], which preserves valuable information about the magmatism and make the OT an ideal area for investigating back-arc magmatic activity.

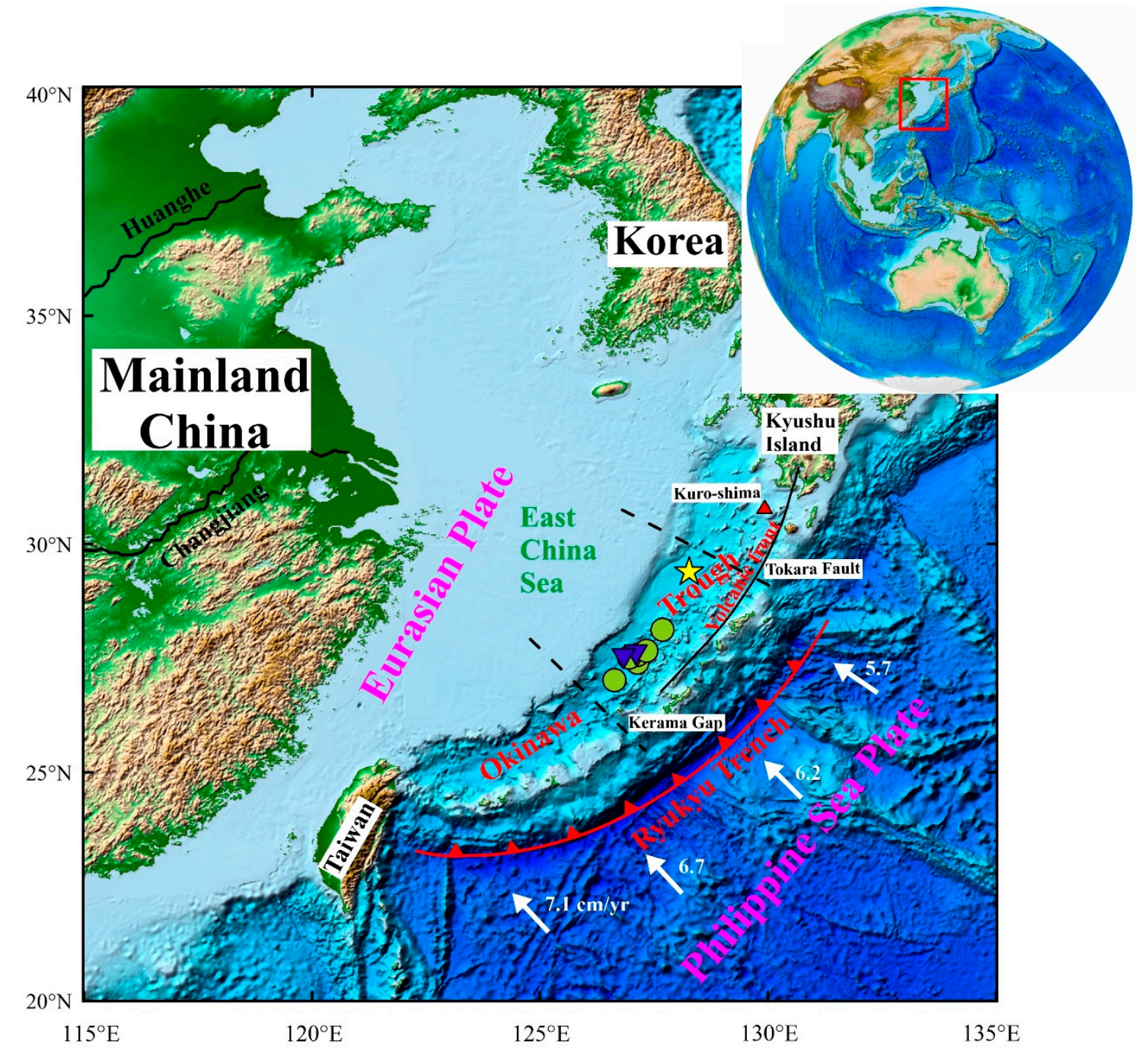

Figure 1. Simplified tectonic map of the Okinawa Trough (OT), showing sampling locations of the studied pumice and volcanic rocks used in this study. Yellow star represents the sampling location of core S9. Blue inverted triangles and green circles represent andesites [26] and basalts [16,17,24,27] from the middle OT (MOT), respectively. Red triangle represents a Quaternary volcano named Kuro-shima [37]. Two black dashed lines represent the Tokara Fault and Kerama Gap [12]. Solid arrows indicate plate motion vectors of the Philippine Sea Plate relative to the Eurasian Plate [35].

All pumice reported in this study was recovered from piston core S9, which was collected from the MOT at a water depth of $1062 \mathrm{~m}$ (Figure 1) with a piston corer. The total length of core S9 was $251 \mathrm{~cm}$. Volcanic materials in S9 were mainly composed of pumice clasts that were found between 226 and $237 \mathrm{~cm}$ with sizes of $0.5-15 \mathrm{~mm}$ and a grayish white color (Figure 2). All of the pumice samples were 
glassy, fresh, and slightly porphyritic. The main phenocryst minerals are orthopyroxene, amphibole, and Fe-Ti oxides. We sampled the pumice clasts at two-centimeter intervals and numbered them F1-6 for geochemical analysis as shown in Table 1.

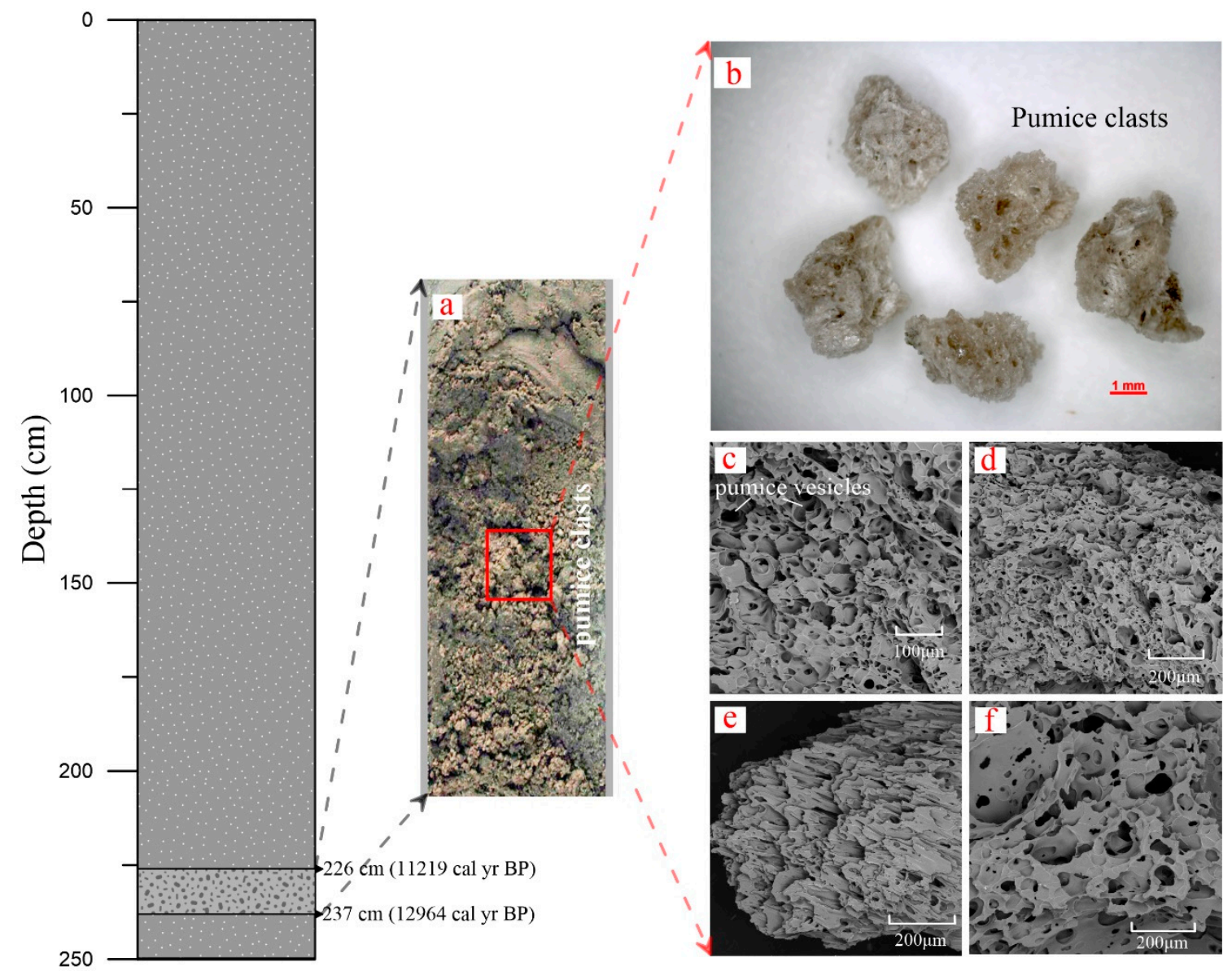

Figure 2. (a) Close-up image of core S9 containing centimeter-thick pumice clasts layers. (b) Hand specimen photographs of pumice recovered from core S9. (c-f) Representative scanning electron microscope (SEM) images of S9 pumice. The eruption ages of S9 pumice samples were calculated with Bayesian analysis.

Table 1. Major and trace elements and $\mathrm{Sr}-\mathrm{Nd}-\mathrm{Pb}$ isotopic compositions of $\mathrm{S} 9$ pumice samples.

\begin{tabular}{ccccccc}
\hline Sample & F1 & F2 & F3 & F4 & F5 & F6 \\
\hline Depth $(\mathrm{cm})$ & $226-227$ & $228-229$ & $230-231$ & $232-233$ & $234-235$ & $236-237$ \\
Major elements (wt.\%) & & & & & & \\
$\mathrm{SiO}_{2}$ & 68.57 & 68.1 & 67.86 & 68.88 & 69.37 & 69.18 \\
$\mathrm{TiO}_{2}$ & 0.63 & 0.69 & 0.68 & 0.65 & 0.67 & 0.63 \\
$\mathrm{Al}_{2} \mathrm{O}_{3}$ & 13.17 & 13.21 & 13.29 & 13.08 & 13.29 & 12.92 \\
$\mathrm{Fe}_{2} \mathrm{O}_{3} \mathrm{~T}$ & 3.53 & 3.81 & 3.67 & 3.53 & 3.6 & 3.31 \\
$\mathrm{MnO}$ & 0.09 & 0.1 & 0.1 & 0.1 & 0.1 & 0.09 \\
$\mathrm{MgO}$ & 0.78 & 0.86 & 0.84 & 0.74 & 0.78 & 0.64 \\
$\mathrm{CaO}$ & 2.57 & 2.73 & 2.61 & 2.51 & 2.55 & 2.28 \\
$\mathrm{Na}$ & 4.02 & 3.99 & 3.98 & 4.05 & 4.06 & 4.06 \\
$\mathrm{~K}_{2} \mathrm{O}$ & 2.59 & 2.53 & 2.48 & 2.59 & 2.59 & 2.7 \\
$\mathrm{P}_{2} \mathrm{O}$ & 0.1 & 0.11 & 0.1 & 0.1 & 0.1 & 0.08 \\
$\mathrm{LOI}$ & 3.78 & 3.45 & 4.17 & 3.67 & 2.75 & 3.78 \\
$\mathrm{Total}$ & 99.82 & 99.58 & 99.77 & 99.9 & 99.85 & 99.68 \\
\hline
\end{tabular}


Table 1. Cont.

\begin{tabular}{|c|c|c|c|c|c|c|}
\hline Sample & F1 & F2 & F3 & F4 & F5 & F6 \\
\hline \multicolumn{7}{|c|}{ Trace elements $(\mu \mathrm{g} / \mathrm{g})$} \\
\hline $\mathrm{Sc}$ & 10.9 & 11.2 & 10.9 & 11.3 & 12.2 & 11.5 \\
\hline $\mathrm{V}$ & 27 & 30 & 30 & 26 & 38 & 23 \\
\hline $\mathrm{Cr}$ & 1 & 2 & 1 & 2 & 1 & 2 \\
\hline Co & 2.3 & 2.6 & 2.6 & 2.4 & 2.9 & 2.4 \\
\hline $\mathrm{Rb}$ & 74.2 & 73.8 & 74.8 & 74.7 & 75.7 & 72.9 \\
\hline $\mathrm{Sr}$ & 151 & 154 & 152.5 & 151.5 & 152.5 & 155 \\
\hline $\mathrm{Y}$ & 33.6 & 33.5 & 33.9 & 33.6 & 32.8 & 33.1 \\
\hline $\mathrm{Zr}$ & 201 & 205 & 207 & 204 & 199 & 198 \\
\hline $\mathrm{Nb}$ & 5.9 & 5.9 & 5.7 & 6 & 6.4 & 6.2 \\
\hline Cs & 3.49 & 3.35 & 3.34 & 3.39 & 3.63 & 3.49 \\
\hline $\mathrm{Ba}$ & 400 & 391 & 399 & 399 & 390 & 394 \\
\hline $\mathrm{La}$ & 18.2 & 18.3 & 18.4 & 18.6 & 18.4 & 18.6 \\
\hline $\mathrm{Ce}$ & 40.4 & 39.4 & 40.7 & 40.9 & 41.2 & 40.8 \\
\hline $\operatorname{Pr}$ & 5.03 & 4.91 & 5.01 & 5.15 & 5.09 & 5.13 \\
\hline $\mathrm{Nd}$ & 20.8 & 20.1 & 20.4 & 20.8 & 20.7 & 21.2 \\
\hline Sm & 5.28 & 4.83 & 4.69 & 5.14 & 4.95 & 4.84 \\
\hline $\mathrm{Eu}$ & 1.06 & 1.06 & 1.09 & 1.12 & 1.08 & 1.15 \\
\hline $\mathrm{Gd}$ & 5.38 & 5.18 & 5.38 & 5.4 & 5.07 & 5.31 \\
\hline $\mathrm{Tb}$ & 0.85 & 0.87 & 0.89 & 0.85 & 0.94 & 0.87 \\
\hline Dy & 5.51 & 5.52 & 5.58 & 5.63 & 5.81 & 5.6 \\
\hline Ho & 1.25 & 1.23 & 1.24 & 1.28 & 1.31 & 1.24 \\
\hline Er & 3.93 & 3.78 & 3.77 & 3.73 & 3.92 & 3.76 \\
\hline $\mathrm{Tm}$ & 0.57 & 0.56 & 0.56 & 0.57 & 0.59 & 0.59 \\
\hline $\mathrm{Yb}$ & 3.88 & 3.72 & 3.8 & 3.78 & 3.94 & 3.86 \\
\hline $\mathrm{Lu}$ & 0.6 & 0.6 & 0.62 & 0.58 & 0.62 & 0.6 \\
\hline $\mathrm{Hf}$ & 5.6 & 5.6 & 5.5 & 5.7 & 5.7 & 5.8 \\
\hline $\mathrm{Ta}$ & 0.46 & 0.48 & 0.41 & 0.43 & 0.49 & 0.47 \\
\hline $\mathrm{Pb}$ & 21.3 & 19.9 & 20.1 & 19.1 & 20.8 & 18.4 \\
\hline Th & 7.27 & 6.87 & 6.98 & 7.09 & 7.32 & 7 \\
\hline U & 1.99 & 2.15 & 2.08 & 2.08 & 2.16 & 1.96 \\
\hline${ }^{87} \mathrm{Sr} /{ }^{86} \mathrm{Sr}$ & - & 0.704857 & 0.704799 & 0.704896 & 0.704941 & 0.705015 \\
\hline${ }^{143} \mathrm{Nd} /{ }^{144} \mathrm{Nd}$ & - & 0.512730 & 0.512732 & 0.512724 & 0.512743 & 0.512736 \\
\hline$\varepsilon N d^{a}$ & - & 1.79 & 1.84 & 1.67 & 2.05 & 1.92 \\
\hline${ }^{206} \mathrm{~Pb} /{ }^{204} \mathrm{~Pb}$ & - & 18.4078 & 18.3763 & 18.3207 & 18.4359 & 18.33 \\
\hline${ }^{207} \mathrm{~Pb} /{ }^{204} \mathrm{~Pb}$ & - & 15.6219 & 15.6241 & 15.6243 & 15.624 & 15.6215 \\
\hline${ }^{208} \mathrm{~Pb} /{ }^{204} \mathrm{~Pb}$ & - & 38.5989 & 38.5719 & 38.5182 & 38.6286 & 38.518 \\
\hline
\end{tabular}

\section{Analytical Methods}

\subsection{Pretreatment of Pumice Samples}

The analyzed pumice clasts in this study were selected from the sediment of core S9. Because pumice vesicles are connected and easily filled by fine-grained sediments, the selected pumice must be effectively cleaned before chemical analyses. The sediments were first placed in a beaker and treated with $5 \% \mathrm{H}_{2} \mathrm{O}_{2}$ at room temperature for at least $12 \mathrm{~h}$ to effectively remove the organic matter. The loose sediments were repeatedly washed with deionized water and dried in an oven at $50{ }^{\circ} \mathrm{C}$ for $24 \mathrm{~h}$ in preparation for selection. After that pumice clasts were selected from the residues with a binocular microscope. To effectively remove the remaining filler in the pumice vesicles, we followed the methods of Huang et al. [25] and Zhang et al. [21] for further washing. The selected pumice clasts were first washed in an ultrasonic cleaner with deionized water, and the water was changed every 20 min until the remaining water was sufficiently clear. Then, pumice samples were treated with $0.5 \mathrm{~mol} / \mathrm{L}$ dilute hydrochloric acid and bathed for two hours at $60^{\circ} \mathrm{C}$ to remove any secondary carbonates and Fe-Mn 
oxides. To completely remove the $\mathrm{Cl}$ ions, pumice clasts were then bathed in hot deionized water for several days, and the water was changed every day until no precipitation formed when $\mathrm{AgNO}_{3}$ was added to the supernatant. After this step, pumice clasts were dried and ground with an agate mortar to a size of 200 mesh for further analysis.

\subsection{Major and Trace Element Analysis}

In this study, the selected six samples of pumice clasts from core S9 were measured for major and trace element contents, and five of them were measured for their $\mathrm{Sr}-\mathrm{Nd}-\mathrm{Pb}$ isotope ratios.

The major element compositions of the pumice samples were determined by X-ray fluorescence (XRF; Phillips PW2404) at the State Key Laboratory of Biogeology and Environmental Geology of China University of Geosciences (Wuhan), China. Aliquots of $0.5000 \pm 0.0005 \mathrm{~g}$ of powdered sample were accurately weighed and mixed with $5 \mathrm{~g}$ of $\mathrm{Li}_{2} \mathrm{~B}_{4} \mathrm{O}_{7}$ to produce fused glass disks at $1050{ }^{\circ} \mathrm{C}$ in an auto-melting prototyping machine for analysis. Loss on ignition (LOI) was determined by the weight difference before and after calcinations at $1000^{\circ} \mathrm{C}$. The certified reference material GSR-3 was also measured many times for data quality control. The analytical precision and accuracy for major elements were generally better than $3 \%$.

All trace element data were obtained by inductively coupled plasma mass spectrometry (ICP-MS; Perkin Elmer Elan 9000) at the ALS Laboratory in Guangzhou, China. Approximately $40 \mathrm{mg}$ of sample powder was weighed and completely digested with concentrated $\mathrm{HF}-\mathrm{HNO}_{3}-\mathrm{HClO}_{4}$ in an airtight Teflon container. The solution was diluted to approximately $40 \mathrm{~g}$ with ultrapure water for testing. Certified reference standards GBM908-10, MRGeo08, OGGeo08, OREAS-45e, OREAS 120, OREAS 460, OREAS-100a, and SY-4 were measured repeatedly with the samples for assessing the analytical results. The precision and accuracy of trace element analysis were generally better than $5 \%$.

\section{3. $\mathrm{Sr}-\mathrm{Nd}-\mathrm{Pb}$ Isotope Analysis}

$\mathrm{Sr}-\mathrm{Nd}$-Pb isotope compositions were measured on a thermal ionization mass spectrometer MAT-262 (Finnigan Company, Germany) at the Radiogenic Isotope Geochemistry Laboratory, University of Science and Technology of China. Approximately $100 \mathrm{mg}$ of powdered samples was placed in a $15 \mathrm{~mL}$ Teflon container. Then, 8-10 drops of purified $\mathrm{HClO}_{4}$ and 2-3 $\mathrm{mL}$ of purified HF were added, followed by airtight heating for approximately one week to fully dissolve the samples. The separation and purification of $\mathrm{Sr}-\mathrm{Nd}-\mathrm{Pb}$ isotopes are different. In detail, $\mathrm{Sr}$ isotopes were obtained from a quartz exchange column with $5 \mathrm{~mL}$ AG50W-X12 exchange resin (200-400 mesh), $\mathrm{Nd}$ isotopes were obtained from a quartz exchange column with $1.7 \mathrm{~mL}$ Teflon powder, and $\mathrm{Pb}$ isotopes were obtained from an AG1-X8 anion exchange resin. Additionally, $\mathrm{Sr}$ isotope ratios were measured by the Ta metal band and Ta emitter, $\mathrm{Nd}$ isotope ratios were measured by the Re metal band, $\mathrm{Pb}$ isotope ratios were measured by the Re metal band with silica gel as emitter. The values of ${ }^{86} \mathrm{Sr} /{ }^{88} \mathrm{Sr}=0.1194$ and ${ }^{146} \mathrm{Nd} /{ }^{144} \mathrm{Nd}=0.7219$ were used for mass fractionation calibration of the measured $\mathrm{Sr}$ and $\mathrm{Nd}$ isotopic ratios. The long-term measurement results of standard solution NBS987 was ${ }^{87} \mathrm{Sr} /{ }^{86} \mathrm{Sr}=0.710249 \pm 0.000012(2 \sigma, n=38)$ and that of standard solution La Jolla was ${ }^{143} \mathrm{Nd} /{ }^{144} \mathrm{Nd}=0.511869 \pm 0.000006(2 \sigma, n=25)$. The measured results of $\mathrm{Pb}$ standard solution NBS981 was used for mass fractionation calibration of $\mathrm{Pb}$ isotopes. Multiple measurement results showed that the fractionation coefficient of $\mathrm{Pb}$ isotopes was $0.1 \%$ per atomic mass unit at $1300{ }^{\circ} \mathrm{C}$. The accuracies of $\mathrm{Sr}$ and $\mathrm{Nd}$ isotope ratios were better than $0.003 \%$, and those of $\mathrm{Pb}$ isotope ratios were better than $0.01 \%$. During the whole process, the background values of $\mathrm{Sr}, \mathrm{Nd}$ and $\mathrm{Pb}$ isotope analyses of the bulk sample were $<200 \mathrm{pg}$, $<100 \mathrm{pg}$, and $<200 \mathrm{pg}$, respectively. The analytical details were described by Chen et al. [42]. For convenience, ${ }^{143} \mathrm{Nd} /{ }^{144} \mathrm{Nd}$ ratios were converted to $\varepsilon \mathrm{Nd}$ with the chondritic uniform reservoir value of 0.512638 [41].

\subsection{Radiocarbon Dating}

To constrain the eruption age of $\mathrm{S} 9$ pumice samples, planktonic foraminifera from three key layers (220-221, 229-230, and 243-244 cm; including two previous data values from Jiang et al. [43]) were 
selected for radiocarbon dating by using accelerator mass spectrometers (AMS) at the American Beta Analytical Laboratory. AMS ${ }^{14} \mathrm{C}$ age data were calibrated to calendar years before AD 1950 with the CALIB 7.0.4 program, the calibration data set Marine13.14c [44] and Delta $R=39 \pm 18$ [45]. The Bacon software package was used to establish the age-depth model for core S9 [46]. In this study, we define the sedimentary ages of $S 9$ pumice samples as their eruption age.

\section{Geochemical Results}

The measured major element, trace element, and $\mathrm{Sr}-\mathrm{Nd}-\mathrm{Pb}$ isotope compositions of pumice clasts are shown in Table 1.

\subsection{Major and Trace Elements}

All six pumice clasts plot in the field of dacite in the total alkali versus silica (TAS) diagram [47] with $\mathrm{SiO}_{2}$ contents ranging from 67.86-69.37 wt.\% (Figure 3a), relatively lower than most reported pumice data in the MOT $[19,23,26]$. The $\mathrm{K}_{2} \mathrm{O}$ versus $\mathrm{SiO}_{2}$ diagram shows that these pumice belong to medium-K calc-alkaline series (Figure 3b) [48]. Compared with MOT basalts and andesites, $\mathrm{S} 9$ pumice clasts have lower $\mathrm{CaO}\left(2.28-2.73\right.$ wt.\%), $\mathrm{MgO}(0.64-0.86 \mathrm{wt} . \%), \mathrm{Al}_{2} \mathrm{O}_{3}\left(12.92-13.29\right.$ wt.\%), $\mathrm{Fe}_{2} \mathrm{O}_{3}{ }^{\mathrm{T}}$ (3.31-3.81 wt.\%), and $\mathrm{TiO}_{2}\left(0.63-0.69\right.$ wt.\%) concentrations and higher $\mathrm{Na}_{2} \mathrm{O}(3.98-4.06$ wt. $\%)$ and $\mathrm{K}_{2} \mathrm{O}$ (2.48-2.70 wt.\%) contents (Figure 4).

The normal mid-ocean ridge basalt (N-MORB) normalized incompatible element patterns of S9 pumice samples are shown in Figure 5, which for comparison, also includes basalts from the MOT [16,27] and basalts from the northern and middle Ryukyu volcanic front [37]. Consistent with previously published pumice data, S9 pumice samples show pronounced enrichments in large ion lithophile elements (LILEs), Th and $U$, and depletions in high field strength elements (HFSEs), which suggests characteristics of subduction-related magma [49]. Additionally, S9 pumice samples exhibit significant positive $\mathrm{K}$ and $\mathrm{Pb}$ anomalies, negative $\mathrm{Nb}$ and Ta anomalies, and clearly negative $\mathrm{P}$ and $\mathrm{Ti}$ anomalies. Furthermore, highly incompatible trace elements (e.g., $\mathrm{Rb}$ and Ba; Figure 4) exhibit excellent linear correlations among the MOT basalt, andesite, and S9 pumice, whereas compatible elements (e.g., $\mathrm{Co}, \mathrm{Sc}$ and V; Figure 4) decrease with increasing $\mathrm{SiO}_{2}$ content from basalt to $\mathrm{S} 9$ pumice.

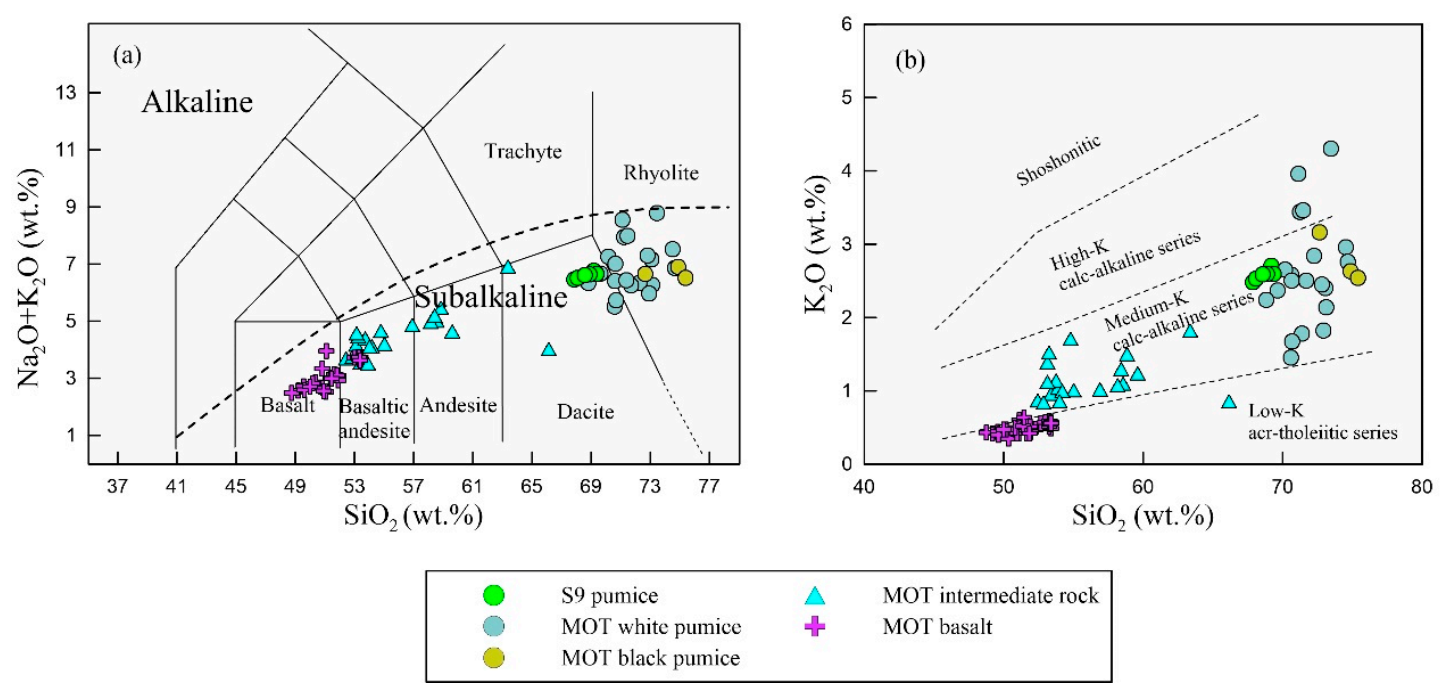

Figure 3. Classification diagrams of $\mathrm{S} 9$ pumice and volcanic rocks from the MOT. (a) Total alkali versus silica (TAS) diagram [47]; (b) $\mathrm{K}_{2} \mathrm{O}$ versus $\mathrm{SiO}_{2}$ diagram, the boundaries of different series were drawn according to [48]. MOT = middle Okinawa Trough. Data sources are from Zhang et al. [23]; Hoang and Uto [27]; Zhai and Gan [16]; Shinjo and Kato [26]; Guo et al. [24]; Guo et al. [19]; Zhai et al. [9]; Huang et al. [25]; Shinjo et al. [17]. 

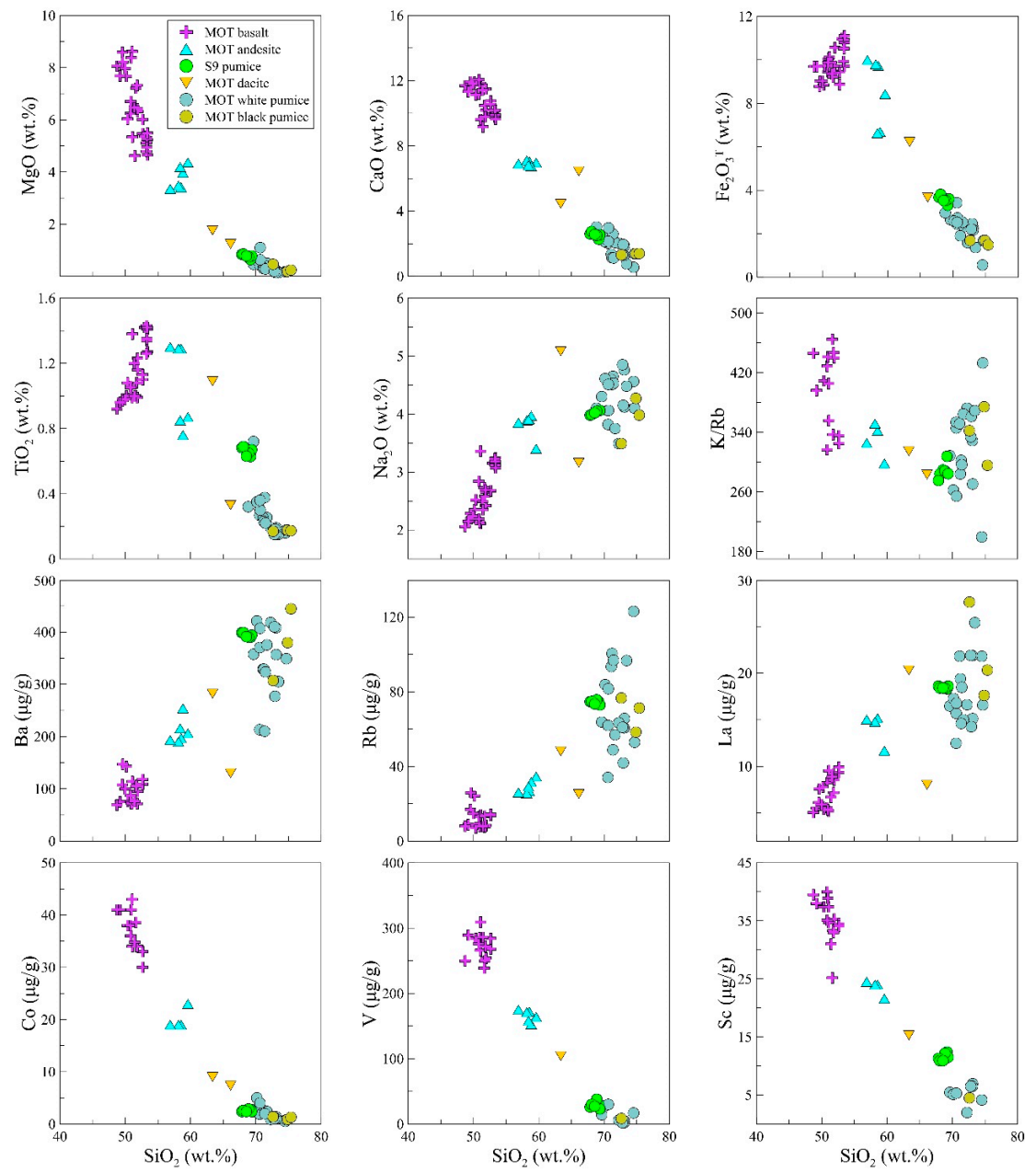

Figure 4. Harker diagrams of S9 pumice samples, basalts, andesites, dacites, and other types of pumice from the MOT. The data sources are the same as in Figure 3.
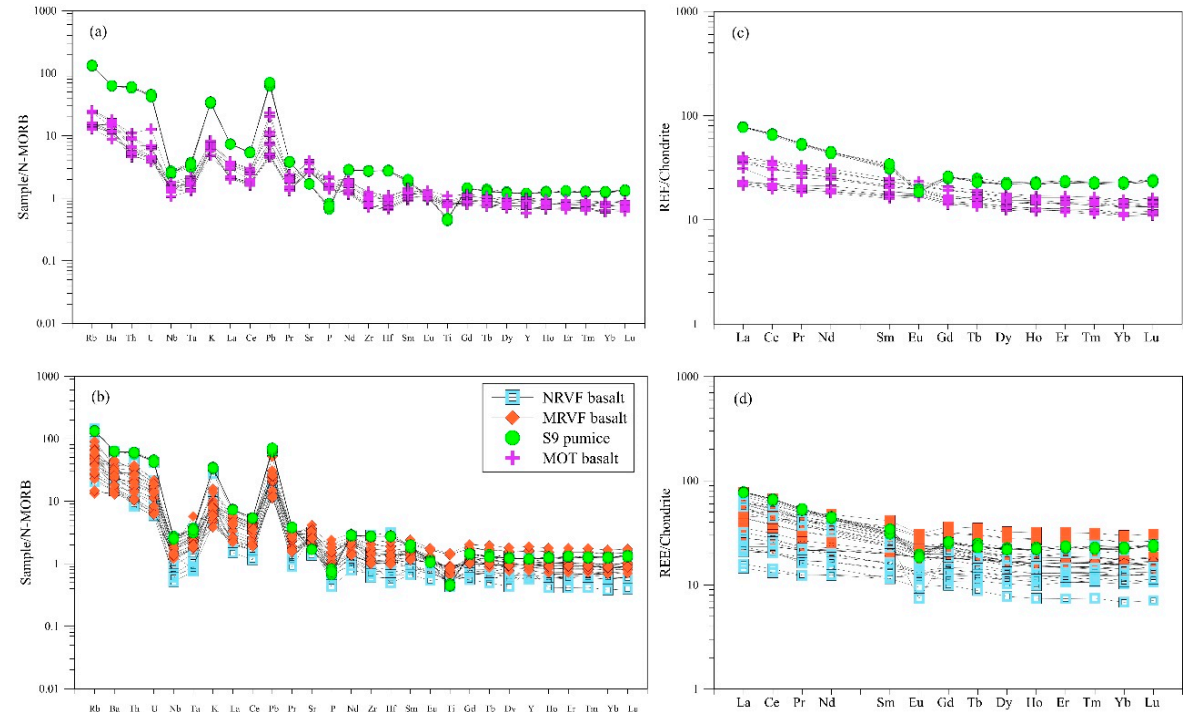

Figure 5. Normal-MORB normalized trace element concentration patterns $(\mathbf{a}, \mathbf{b})$, and chondrite-normalized REE patterns (c,d) for the studied pumice compared with basalts from the MOT [16,17,24,27], and basalts from the northern and central Ryukyu volcanic front [37,50-53]. The normalization constants are from Sun and McDonough [54]. MOT = middle Okinawa Trough; NRVF = northern Ryukyu volcanic front; MRVF = middle Ryukyu volcanic front. 
As shown on the chondrite-normalized rare earth elements (REEs) diagram (Figure $5 c, d$ ), the S9 pumice samples are enriched in light REEs (LREEs) relative to heavy REEs (HREEs) $\left(\left[\mathrm{La}_{N} / \mathrm{Yb}_{\mathrm{N}}\right]=\right.$ $3.35-3.53)$, showing convex downward patterns. The bulk REE values ( $\sum$ REE $\left.=110.06-113.62 \mathrm{ppm}\right)$ of S9 pumice are relatively high compared with those of the associated basalts, almost twice as much as basalt $\sum$ REE values, and the HREE concentrations are also slightly higher than those of basalt. Additionally, REE patterns show pronounced negative Eu anomalies with $\delta \mathrm{Eu}\left(\delta \mathrm{Eu}=2^{*} \mathrm{Eu} /(\mathrm{Sm}+\mathrm{Gd})\right)$ ranging from 0.6 to 0.69 .

\section{2. $\mathrm{Sr}-\mathrm{Nd}$ - $\mathrm{Pb}$ Isotopes}

The isotope data of S9 pumice samples are presented in Table 1. These representative data have also been plotted on various covariation diagrams to allow comparison with rocks from known geological settings [55,56].

On the Sr-Nd isotope diagram (Figure 6), our pumice samples record nearly constant isotopic ratios and plot differently from those of the previously reported volcanic rocks in the MOT. In detail, S9 pumice samples have relatively higher ${ }^{87} \mathrm{Sr} /{ }^{86} \mathrm{Sr}$ ratios $(0.70480-0.70502)$ and lower ${ }^{143} \mathrm{Nd} /{ }^{144} \mathrm{Nd}$ ratios (0.51272-0.51274; $\varepsilon \mathrm{Nd}=1.67-2.05)$ compared with the MOT basalt [57], andesite and type I rhyolite [26] (Table 1). Additionally, these pumice samples have Sr-Nd isotope ratios similar to those of the central Ryukyu basalts $[50,53]$ and plot within the overlapping fields of Indian Ocean MORB and Philippine Sea sediment [57-60] in the Sr-Nd isotope diagrams (Figure 6).

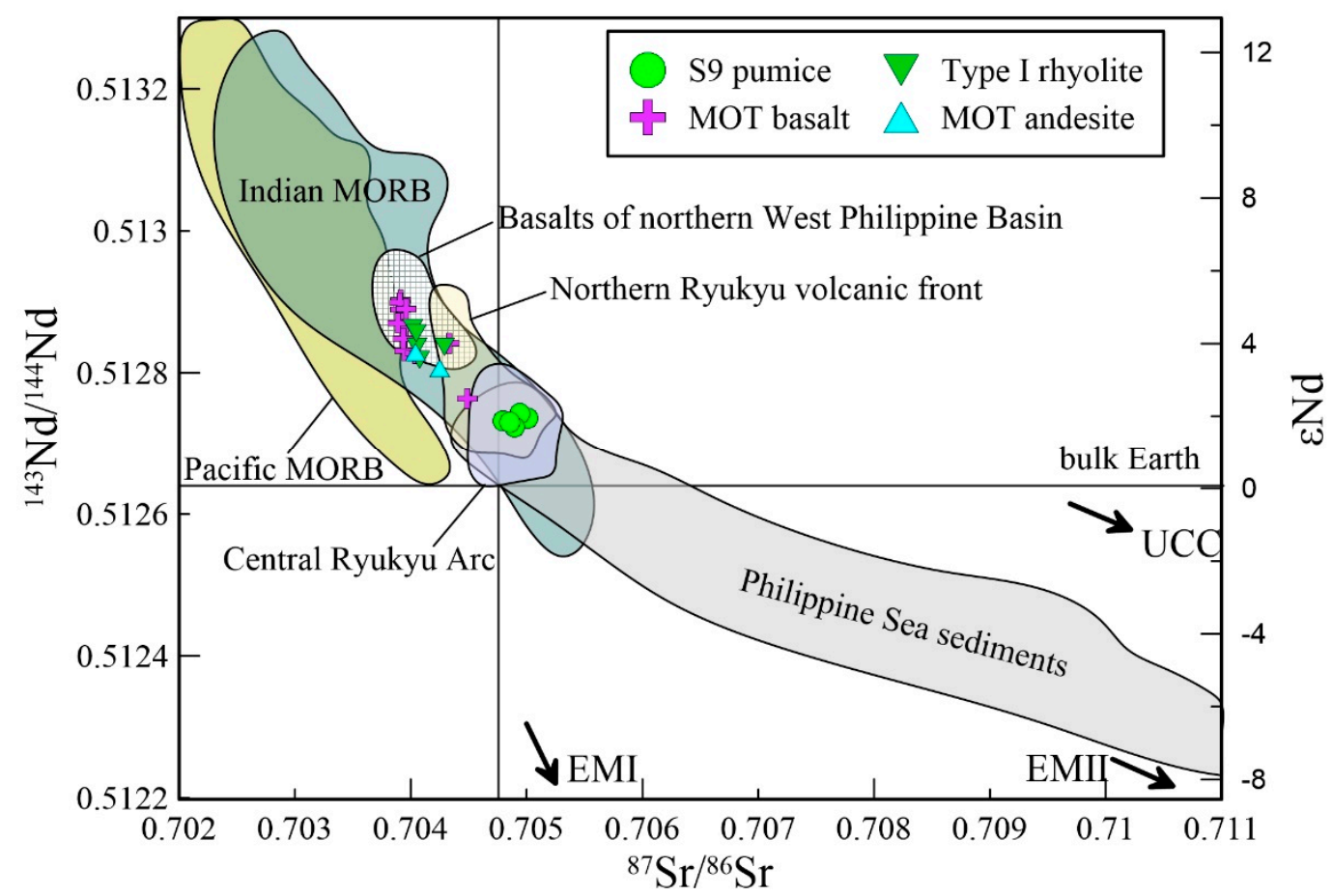

Figure 6. ${ }^{87} \mathrm{Sr} /{ }^{86} \mathrm{Sr}$ versus ${ }^{143} \mathrm{Nd} /{ }^{144} \mathrm{Nd}$ diagram for the studied pumice compared to volcanic rocks from the MOT [17,24,26,27,57], basalts from the northern West Philippine Basin [55,56], basalts from the northern Ryukyu volcanic front [37,50,51], basalts from the central Ryukyu arc [37]. Indian MORB, Pacific MORB and Philippine Sea sediments (PetDB database; http://www.earthchem.org/petdb) are also shown for comparison. EMI and EMII data are from Zindler and Hart [61].

Figure 7 illustrates the $\mathrm{Pb}$ isotope compositions of the samples. Although $\mathrm{S} 9$ pumice samples have ${ }^{206} \mathrm{~Pb} /{ }^{204} \mathrm{~Pb}(18.321-18.436)$ values similar to those of associated basalts, they display different trends on the $\mathrm{Pb}-\mathrm{Pb}$ isotope diagrams. In detail, $\mathrm{S} 9$ pumice samples have nearly constant ${ }^{207} \mathrm{~Pb} /{ }^{204} \mathrm{~Pb}$ values ranging from 15.622 to 15.624 . The values of ${ }^{208} \mathrm{~Pb} /{ }^{204} \mathrm{~Pb}$ are ranging from 38.52 to 38.63 , which are higher than those of MOT basalts and northern Ryukyu volcanic front basalts [37,51,52] (Figure 7). Additionally, 
all these pumice samples lie distinctly above the Northern Hemisphere reference line (NHRL) [62] and are compositionally within the field of southern Kyushu and Indian Ocean MORB (Figure 7).
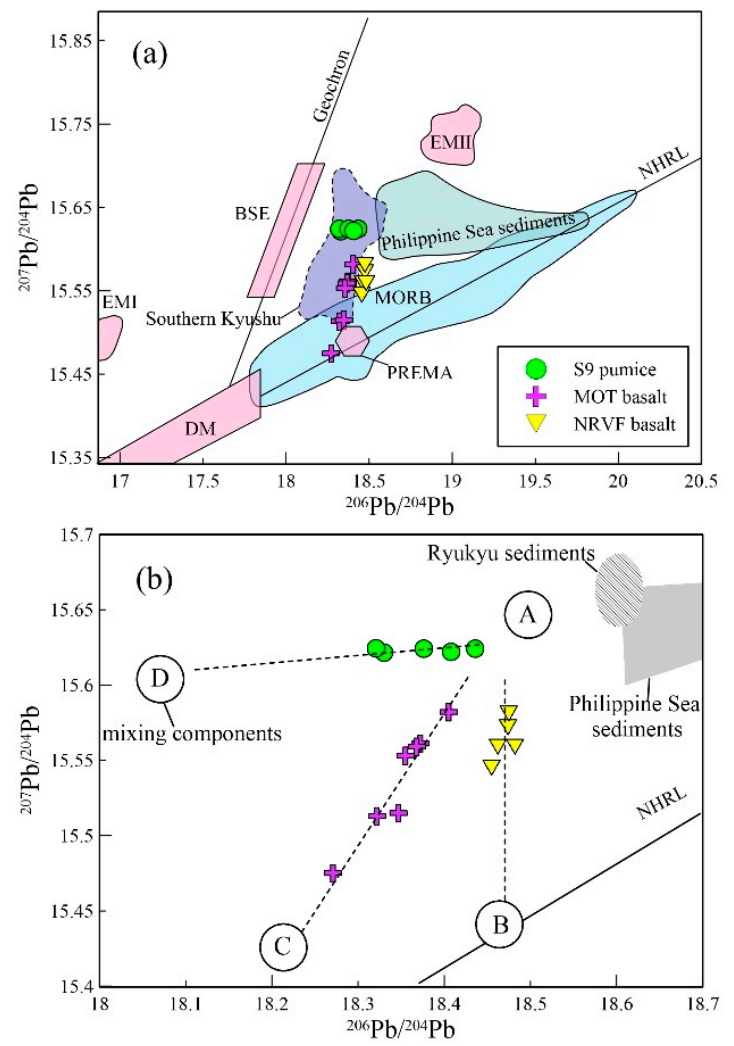
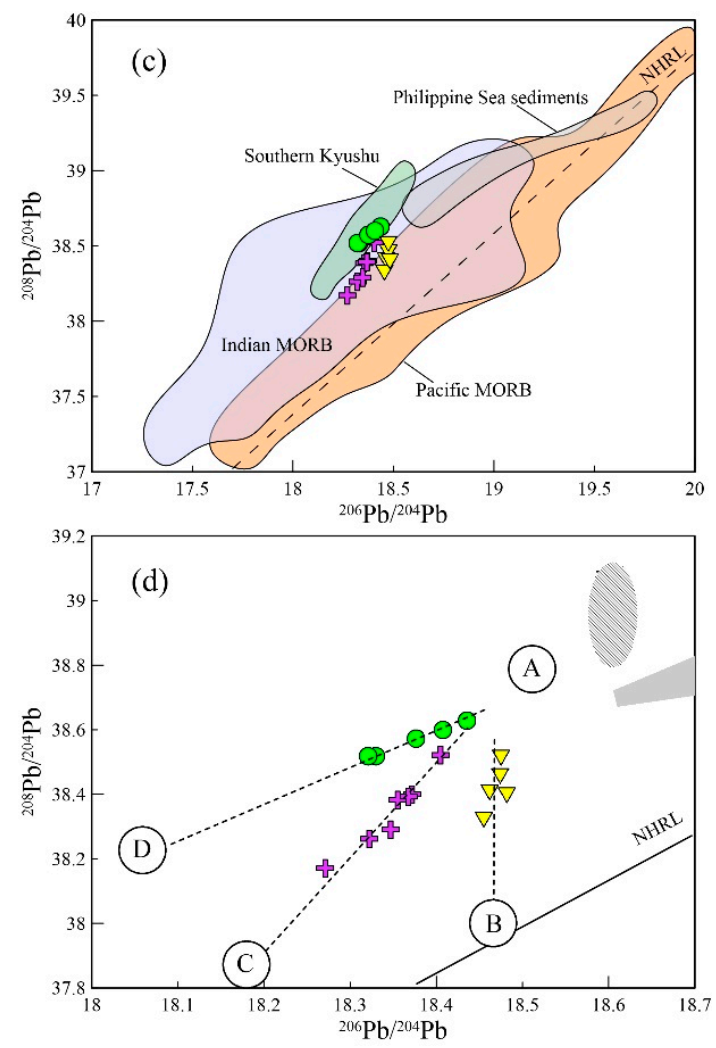

Figure 7. Plots of $(\mathbf{a}, \mathbf{b}){ }^{207} \mathrm{~Pb} /{ }^{204} \mathrm{~Pb}$ versus ${ }^{206} \mathrm{~Pb} /{ }^{204} \mathrm{~Pb}$ and $(\mathbf{c}, \mathbf{d}){ }^{208} \mathrm{~Pb} /{ }^{204} \mathrm{~Pb}$ versus ${ }^{206} \mathrm{~Pb} /{ }^{204} \mathrm{~Pb}$ diagrams of S9 pumice samples and basalts from the MOT [17,57] and its adjacent regions. The Northern Hemisphere reference line (NHRL) [62] and representative fields (DM, EMI, EMII, PREMA, and BSE) [61] are shown for reference. Yellow inverted triangles represent basalts from the southern segment of northern Ryukyu volcanic front [37]. Data of Indian MORB and Pacific MORB are from PetDB database (http://www.earthchem.org/petdb), data of Philippine Sea sediments are from Hauff et al. [58], Plank and Langmuir [59], and Shu et al. [57]. Letters A-D in (b) and (d) represent different components discussed in the text. MOT = middle Okinawa Trough. NRVF = northern Ryukyu volcanic front.

\section{Discussion}

\subsection{Constraints on Eruption Age}

Reliable chronological framework form a basis for precise and quantitative analyses of geological processes [63]; however, eruption ages for volcanic rocks in the OT are deficient due to the difficulties in dating young geological material [64-66]. The OT is a young and active back-arc basin with volcanic activity younger than $4 \mathrm{Ma}$ [31]. Chen et al. [30] and Huang et al. [25] used the U-series disequilibrium dating method to determine the ages of felsic volcanic rocks in the OT, and both imply a widespread felsic volcanic activity in the late Pleistocene.

As mentioned above, pumice clasts used in this study were selected from sediment core S9, all samples are fresh with sharp edges and corners (Figure 2b). Previous studies have suggested that all the vesicles in pumice are connected [67] and their density are lower than seawater [19]. Nevertheless, most pumice clasts sink immediately upon immersion in water after explosive volcanism [68], which means pumice is unlikely to float far and the buoyancy of freshly erupted submarine pumice is transient, especially when the pumice is hot and has erupted from the deep seafloor (e.g., depths > 200 $\mathrm{m}$, temperatures $>300^{\circ} \mathrm{C}$ ) $[68,69]$. In addition, studies on pumice associated with the OT have all regarded the rocks as products of back-arc volcanism $[19,23,26]$. These results suggest that pumice 
samples deposited in core S9 were close to the eruption center with short-distance transportation. Therefore, we are confident that the eruption ages of pumice samples used in this study can be well constrained with the radiocarbon dating data of planktonic foraminifera.

To establish a reliable and probabilistic age framework, Bayesian accumulation histories for deposits are the best choice to constrain the sedimentation history of the investigated layers [70]. In this study, Bayesian statistics were performed by using the Bacon R software (v2.3.5) [46] to reconstruct an age-depth model for $\mathrm{S} 9$ by combining radiocarbon dates with prior information. Detailed analytical procedures were given in Blaauw and Christen [46]. The age-depth model was developed on the basis of three ${ }^{14} \mathrm{C}$ ages of foraminifera selected from layers at 220-221, 229-230, and 243-244 cm (Table 2), and the results have a 95\% confidence interval. As shown in Table 3, the ages of S9 pumice samples are between $11.22 \mathrm{cal}$. ka BP and $12.96 \mathrm{cal}$. ka BP, corresponding well with felsic volcanic activity that occurred during the late Pleistocene and early Holocene [25,30]. Thus, we reasonably infer that an approximately 1.74-kyr eruption record is well preserved in core S9.

Table 2. Radiocarbon dating data for core S9.

\begin{tabular}{cccccc}
\hline Depth (cm) & Material & AMS $^{\mathbf{1 4}} \mathbf{C}$ Age (yr BP) & $\pm \mathbf{1 \sigma}$ & Calendar Age (cal yr BP) & $\pm \mathbf{2 \sigma}$ \\
\hline $220-221$ & Planktonic foraminifera & $9050^{\text {a }}$ & 30 & 9675 & 142.5 \\
$229-230$ & Planktonic foraminifera & 10750 & 40 & 11972 & 236 \\
$243-244$ & Planktonic foraminifera & $12437^{\text {a }}$ & 30 & 13877 & 128.5 \\
\hline \multicolumn{7}{c}{ a data cited from Jiang et al. [43]. }
\end{tabular}

Table 3. The calculated eruption ages of S9 pumice samples.

\begin{tabular}{cccc}
\hline Sample & Depth (cm) & Eruption Ages (Cal. yr BP) & $\pm \mathbf{2 \sigma}$ \\
\hline F1 & $226-227$ & 11219 & 214 \\
F2 & $228-229$ & 11718 & 235 \\
F3 & $230-231$ & 12220 & 189.5 \\
F4 & $232-233$ & 12470 & 198 \\
F5 & $234-235$ & 12708 & 142.5 \\
F6 & $236-237$ & 12964 & 149.5 \\
\hline
\end{tabular}

\subsection{The origin of S9 Pumice}

The formation of volcanic rocks in the OT is complex due to the variable Quaternary magmatic activity in the three different segments $[11,12,16,17]$. Although grayish white pumice is widely distributed in the OT, its origin remains controversial due to the lack of available isotope data and an age framework. Previous studies suggest that there are different types of pumice with various compositions in the OT, and different models were carried out to interpret their formations: (1) most of the studies accept that rhyolitic magmas are derived from basaltic magmas through fractional crystallization or assimilation and fractional crystallization (AFC) rather than through partial melting, as they have similar Sr-Nd isotope compositions [9,19]; (2) Zhang et al. [23] proposed that the partial melting of cognate mafic to intermediate igneous rocks could also generate rhyolites with similar Sr-Nd isotope compositions.

\subsubsection{Fractional Crystallization}

Major element concentrations of $\mathrm{S} 9$ pumice samples (e.g., $\mathrm{MgO}$ and $\mathrm{CaO}$ ) display a linear trend with the MOT basalts and andesites (Figure 4). The concentrations of incompatible trace elements (e.g., $\mathrm{Ba}$ and La) gradually increase while the concentrations of compatible trace elements (e.g., Co and V) decrease with increasing $\mathrm{SiO}_{2}$ contents from MOT basaltic rocks to andesites to $\mathrm{S} 9$ pumice samples (Figure 4). These results indicate a magmatic evolution process from basaltic to felsic volcanic rocks. In addition, evidence from other representative elements (e.g., $\mathrm{P}, \mathrm{Ti}$, and $\mathrm{Eu}$ ) also suggests a process of fractional crystallization. 
In the early stage of magmatic crystallization, Ti and P can enter mineral phases and form ilmenite, titanomagnetite, and apatite, resulting in depletion of these elements in the residual melt during the later stage of magma evolution [19]. In the N-MORB-normalized trace element patterns, strong depletions in $\mathrm{P}$ and $\mathrm{Ti}$ in $\mathrm{S} 9$ pumice samples compared with associated basalts likely suggest fractionation of apatite and Fe-Ti oxides (Figure 5). Similar to volatiles, P generally shows enrichment during the late stage of felsic magmatic evolution [54]. However, $\mathrm{P}$ in this study shows evident depletion, further indicating that the $\mathrm{S} 9$ pumice are not derived from felsic magma. The $\mathrm{K} / \mathrm{Rb}$ versus $\mathrm{SiO}_{2}$ diagram among MOT basalt, andesite, and S9 pumice display a decreasing trend (Figure 4), which may be attributed to fractional crystallization of hornblende and this is consistent with our observation that small amount of the hornblende can be observed in S9 pumice samples. During the process of magmatic fractional crystallization, the crystallization of plagioclase generally leads to a significant negative Eu anomaly in the residual melt $[15,19]$. The chondrite-normalized REE patterns of S9 pumice displays a trend subparallel to that of the MOT basalts with obvious negative Eu anomalies $(\delta \mathrm{Eu}=0.60-0.69$; Figure 5$)$, which suggests that the magma experienced the crystallization of plagioclase. All of these findings imply that the parent magma of S9 pumice clasts experienced a crystal fractionation process.

\subsubsection{Magma Sources of S9 Pumice}

The $\mathrm{SiO}_{2}$ contents of pumice clasts in this study $(67.86-69.37 \mathrm{wt} . \%)$ are relatively lower than those of previously reported pumice in the MOT (generally $>70 \mathrm{wt} . \%$ ) $[19,23,26]$, suggesting that $\mathrm{S} 9$ pumice may have different magma sources.

Studies about the magma sources of volcanic rocks in the OT were carried out since the early 1990s $[7,17]$. These studies have proposed that isotopic compositions provide valuable information about regional magmatic activity and evolution. However, available isotopic data are relatively few (especially $\mathrm{Pb}$ isotope compositions), and the source type of magma remains controversial despite many previous studies $[23,26,38]$. In this study, we use trace elements and $\mathrm{Sr}-\mathrm{Nd}-\mathrm{Pb}$ isotope compositions and characteristics to perform reliable analysis for the magma sources of S9 pumice. This study further confirms the well-recognized concept that magma of the back-arc basin have a complex multisource origin [12,71].

The OT is a back-arc basin located behind the Ryukyu arc-trench system that has developed above the subduction zone [35,72]. The mantle wedge beneath the Ryukyu volcanic arc is affected by various subduction components (e.g., sediments, fluids and altered oceanic crust) [37]. Therefore, the nature of the mantle wedge and the subduction components are key factors in analyzing the origins of volcanic rocks from the OT. There are two main viewpoints regarding the nature of the mantle wedge in the study area: Indian MORB-type mantle and the Pacific MORB-type mantle [12,27]. Figure 7 shows variations in ${ }^{207} \mathrm{~Pb} /{ }^{204} \mathrm{~Pb}$ versus ${ }^{206} \mathrm{~Pb} /{ }^{204} \mathrm{~Pb}$ and ${ }^{208} \mathrm{~Pb} /{ }^{204} \mathrm{~Pb}$ versus ${ }^{206} \mathrm{~Pb} /{ }^{204} \mathrm{~Pb}$, along with the values of basalts from the MOT and the southern segment of northern Ryukyu volcanic front. These samples apparently define three distinctly separate trends and reflect the mixing of subduction components and the mantle, although components $\mathrm{A}, \mathrm{B}, \mathrm{C}$, and $\mathrm{D}$ may not represent the exact $\mathrm{Pb}$ isotopic compositions of these end members.

Figure $7 b$, d show that component $\mathrm{A}$ is characterized by high ${ }^{206} \mathrm{~Pb} /{ }^{204} \mathrm{~Pb},{ }^{207} \mathrm{~Pb} /{ }^{204} \mathrm{~Pb},{ }^{208} \mathrm{~Pb} /{ }^{204} \mathrm{~Pb}$ concentrations, which is consistent with the upper continent crust. This feature can be explained by the sediment derived from the subducting Philippine Sea plate [37,57], which is widely considered to be a potential source of volcanic rocks in the OT [19,27,57,71]. Shinjo et al. [37] suggests that component B is most likely the Pacific Ocean MORB-type mantle. The effect of Pacific Ocean MORB-type mantle on OT magma is limited to the northeastern end of the NOT, and the boundary between the Indian Ocean MORB-type and the Pacific Ocean MORB-type possibly lies between Kuro-Shima and the northern segment of the north Ryukyu volcanic front (Figure 1) [12,27,37]. Please note that core S9 is located at the southwestern side of the boundary (Figure 1), and the $\mathrm{Pb}$ isotope characteristics of MOT basalts are convergent along the mixing line between component $\mathrm{A}$ and $\mathrm{C}$ (Figure $\mathrm{7b}, \mathrm{d}$ ). Evidence from $\mathrm{Pb}$ isotope composition have indicated that the eastern Asian-western Pacific asthenosphere resembles 
Indian Ocean MORB [73]. Findings from Guo et al. [19] and Chen et al. [71] have also suggested that the mantle wedge beneath in the middle and southern part of the OT is Indian Ocean MORB-type. Sr, $\mathrm{Nd}$, and $\mathrm{Pb}$ isotope compositions have also shown that MOT basalt, andesite, type I rhyolite and $\mathrm{S} 9$ pumice are well within the Indian MORB-type field (Figures 6 and 7) [54,74]. Consequently, we infer that component $C$ is most likely the Indian Ocean MORB-type mantle.

S9 pumice samples have relatively high ${ }^{207} \mathrm{~Pb} /{ }^{204} \mathrm{~Pb}$ and ${ }^{208} \mathrm{~Pb} /{ }^{204} \mathrm{~Pb}$ ratios and clearly plot leftward, trending towards an enriched mantle I (EMI)-like endmember (Figure 7a,b). This trend is different from that of basalts and seems difficult to be explained by mixing Indian Ocean MORB-type mantle and subducted sediment. This indicates that an isotopically distinct component may be responsible for this phenomenon, i.e., a component with low ${ }^{206} \mathrm{~Pb} /{ }^{204} \mathrm{~Pb}$ and relatively high ${ }^{207} \mathrm{~Pb} /{ }^{204} \mathrm{~Pb}$ ratios compared with depleted mantle. Similar characteristics are shown in ${ }^{87} \mathrm{Sr} /{ }^{86} \mathrm{Sr}$ versus ${ }^{143} \mathrm{Nd} /{ }^{144} \mathrm{Nd}$ diagram (Figure 6), S9 pumice samples have lower ${ }^{143} \mathrm{Nd} /{ }^{144} \mathrm{Nd}$ and higher ${ }^{87} \mathrm{Sr} /{ }^{86} \mathrm{Sr}$ than the MOT basalts and plots closer to EMI-like mantle material [61]. This further suggests that an EMI-like component might have contributed to the magmatic compositions of S9 pumice. This finding is in agreement with previous studies from the OT $[17,19,27]$. Generally, crustal contamination may lead to increases in $\mathrm{SiO}_{2}$ and incompatible element contents and decreases in most compatible element contents [13,37]. In Figure 8, our geochemical data are compared with available data of basalts and andesites from the MOT. Figure 8 shows that $\mathrm{Sr}-\mathrm{Nd}$ isotope compositions have linear correlations with $\mathrm{SiO}_{2}$ and $\mathrm{MgO}$ contents among the MOT basalts, andesites, and $\mathrm{S} 9$ pumice samples. $\mathrm{SiO}_{2}$ correlate positively with ${ }^{87} \mathrm{Sr} /{ }^{86} \mathrm{Sr}$ and negatively with ${ }^{143} \mathrm{Nd} /{ }^{144} \mathrm{Nd}$ (Figure $8 \mathrm{a}$, d), while $\mathrm{MgO}$ correlate negatively with ${ }^{87} \mathrm{Sr} /{ }^{86} \mathrm{Sr}$ and positively with ${ }^{143} \mathrm{Nd} /{ }^{144} \mathrm{Nd}$ (Figure $8 \mathrm{~b}, \mathrm{e}$ ), indicating a crustal assimilation process. Additionally, ${ }^{87} \mathrm{Sr} /{ }^{86} \mathrm{Sr}$ gradually increases, while ${ }^{143} \mathrm{Nd} /{ }^{144} \mathrm{Nd}$ decreases with increasing $\mathrm{Th} / \mathrm{La}$ ratios among the MOT basalts, andesites, and S9 pumice (Figure $8 \mathrm{c}, \mathrm{f}$ ). These results suggest that the variations in the chemical and isotopic compositions of S9 pumice samples may reflect the process of crustal contamination in the MOT. Accordingly, this enriched component and crustal assimilation revealed by the geochemical characteristics of S9 pumice may most likely indicate the contribution of the lower crust, which has higher ${ }^{87} \mathrm{Sr} /{ }^{86} \mathrm{Sr}$ and much lower ${ }^{143} \mathrm{Nd} /{ }^{144} \mathrm{Nd}$ ratios than $\mathrm{S} 9$ pumice. Some lower crustal xenoliths from North China and lower crustal granodiorite from southern Kyushu generally yield higher ${ }^{87} \mathrm{Sr} /{ }^{86} \mathrm{Sr}$ ratios and much lower ${ }^{143} \mathrm{Nd} /{ }^{144} \mathrm{Nd}$ ratios than $\mathrm{S} 9$ pumice [75-78]. Letouzey and Kimura [72] suggested that the middle and northern parts of the OT were an uplifted land area constructed from Cretaceous granite and older host rocks before the late Miocene. In addition, Cretaceous granite fragments were obtained by dredging and coring in the OT [79,80]. Kizaki [28] suggested that the geological characteristics beneath the central grabens of the OT are similar to that of the Inner Zone of southwest Japan, which is featured by abundant exposures of Cretaceous to Paleogene felsic volcanic and plutonic rocks. The Sr-Nd isotope compositions of granites from the Kyushu Island display the signature of the lower crust $[77,78]$, which can be used as representative of the lower crustal endmember.

To further verify our hypothesis, two endmember isotopic models are used to perform calculations of magmatic compositions for S9 pumice (Figures 9 and 10, Table 4) and establish their potential links with MOT basalts. The isotopic ratios and element concentrations of the endmembers used in this study are listed in Table 4. In the Sr-Nd isotope mixing model (Figure 9), variations in ${ }^{87} \mathrm{Sr} /{ }^{86} \mathrm{Sr}$ and ${ }^{143} \mathrm{Nd} /{ }^{144} \mathrm{Nd}$ ratios of S9 pumice samples, basalts, andesites, and type I rhyolite from the MOT indicate genetic difference among these volcanic rocks (i.e., they have different magmatic compositions). The isotopic characteristics of S9 pumice samples have suggested that their magmatic compositions may contribute from the Indian Ocean MORB-type mantle, the Philippine Sea sediments, and EMI-like component (Figures 6 and 7). The geochemical compositions of S9 pumice have also suggested the occurrence of crustal assimilation during the magmatic ascent process (Figure 8). Therefore, upper continent crust (UCC) [81-83] is considered to be another endmember to evaluate the effect of contamination and deduce the magmatic composition of S9 pumice. 


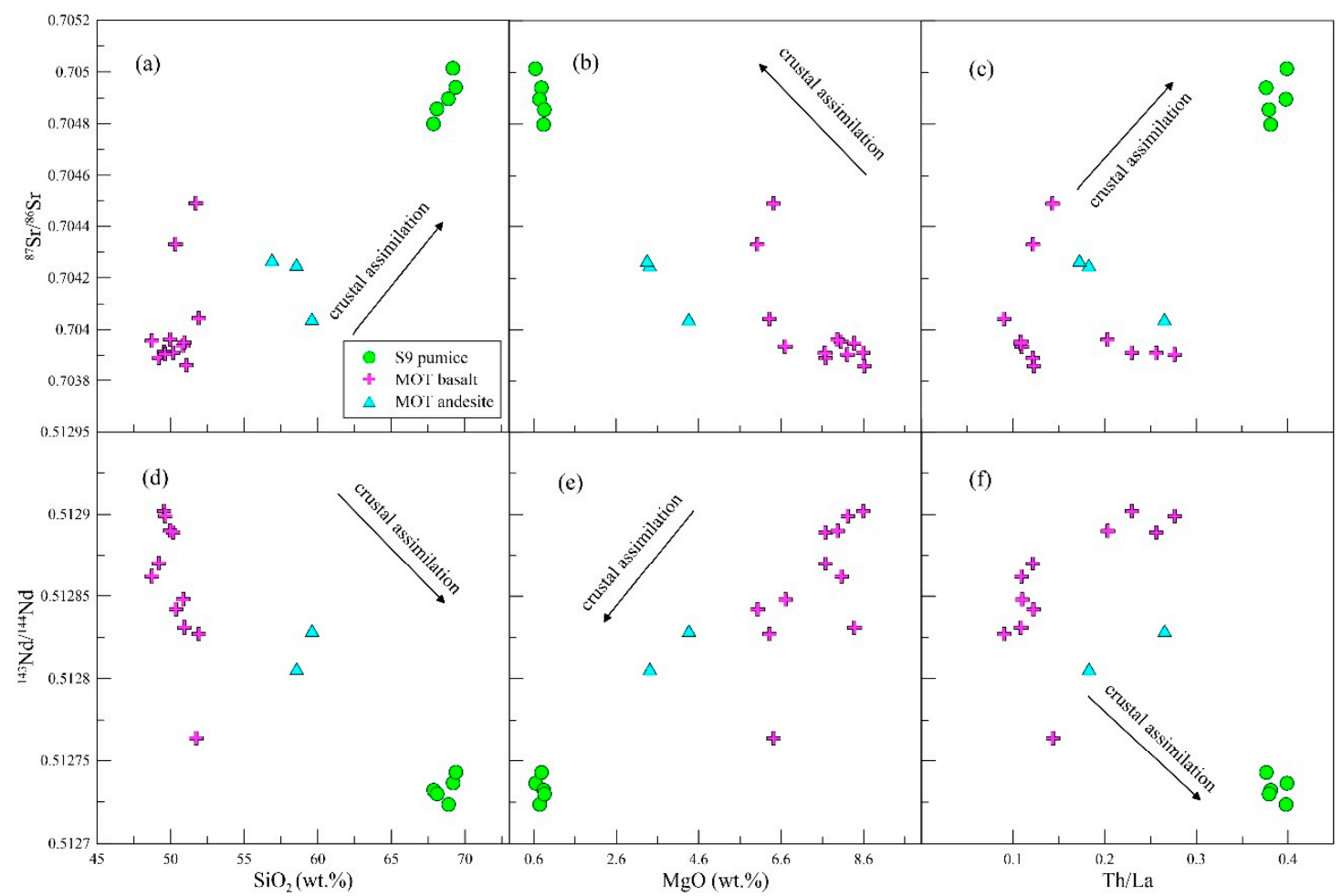

Figure 8. Plots of $(\mathbf{a}-\mathbf{c}){ }^{87} \mathrm{Sr} /{ }^{86} \mathrm{Sr}$ versus $\mathrm{SiO}_{2}, \mathrm{MgO}$, and $\mathrm{Th} / \mathrm{La}$, and $(\mathbf{d}-\mathbf{f}){ }^{143} \mathrm{Nd} /{ }^{144} \mathrm{Nd}$ versus $\mathrm{SiO}_{2}$, $\mathrm{MgO}$, and $\mathrm{Th} / \mathrm{La}$ diagrams for the studied pumice and volcanic rocks from the MOT. The source data of volcanic rocks from the MOT are the same as in Figure 6. MOT = middle Okinawa Trough.

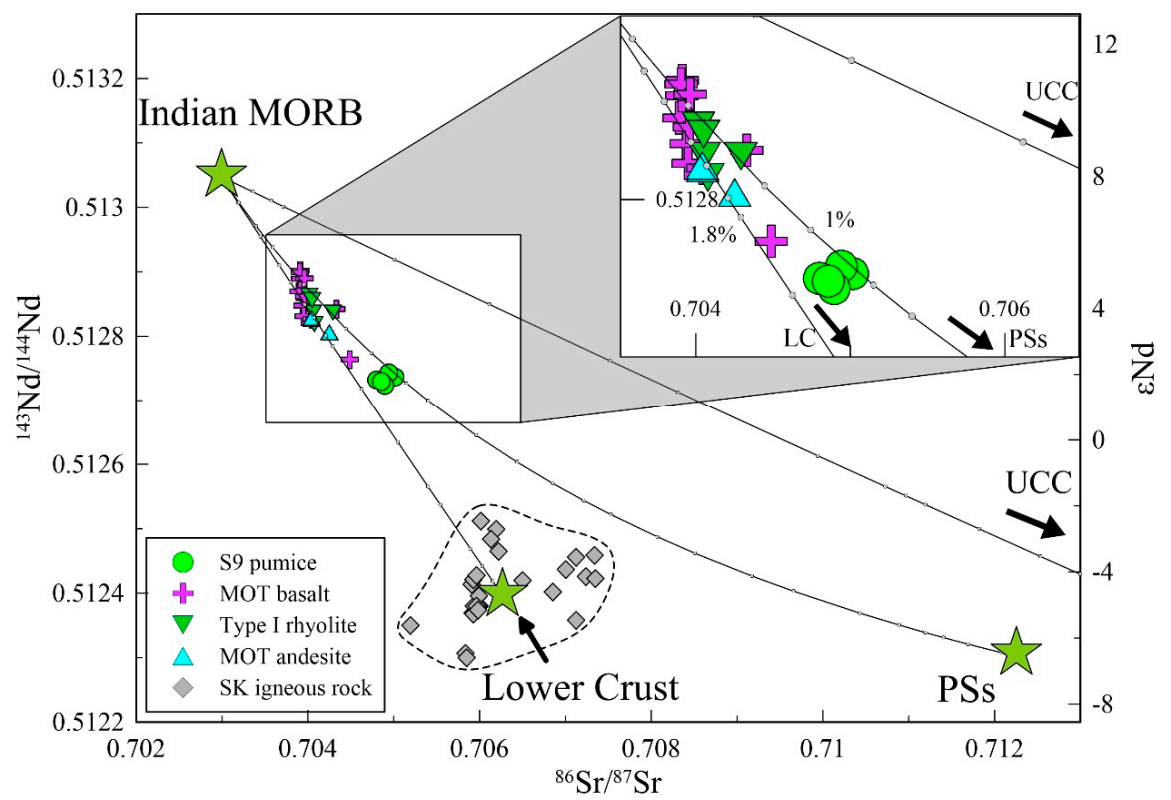

Figure 9. Calculation diagram of ${ }^{87} \mathrm{Sr} /{ }^{86} \mathrm{Sr}$ versus ${ }^{143} \mathrm{Nd} /{ }^{144} \mathrm{Nd}$ for $\mathrm{S} 9$ pumice samples and volcanic rocks from the MOT. Igneous rocks from the southern Kyushu, which exhibit a lower crustal provenance are also shown for comparison $[13,77,78]$. The black lines represent mixing between two endmembers (UCC = upper continental crust; PSs = Philippine Sea sediments; SK = southern Kyushu). The compositions of endmembers used for the calculations are listed in Table 4. MOT = middle Okinawa Trough. The source data of volcanic rocks in the MOT are the same as in Figure 6. 


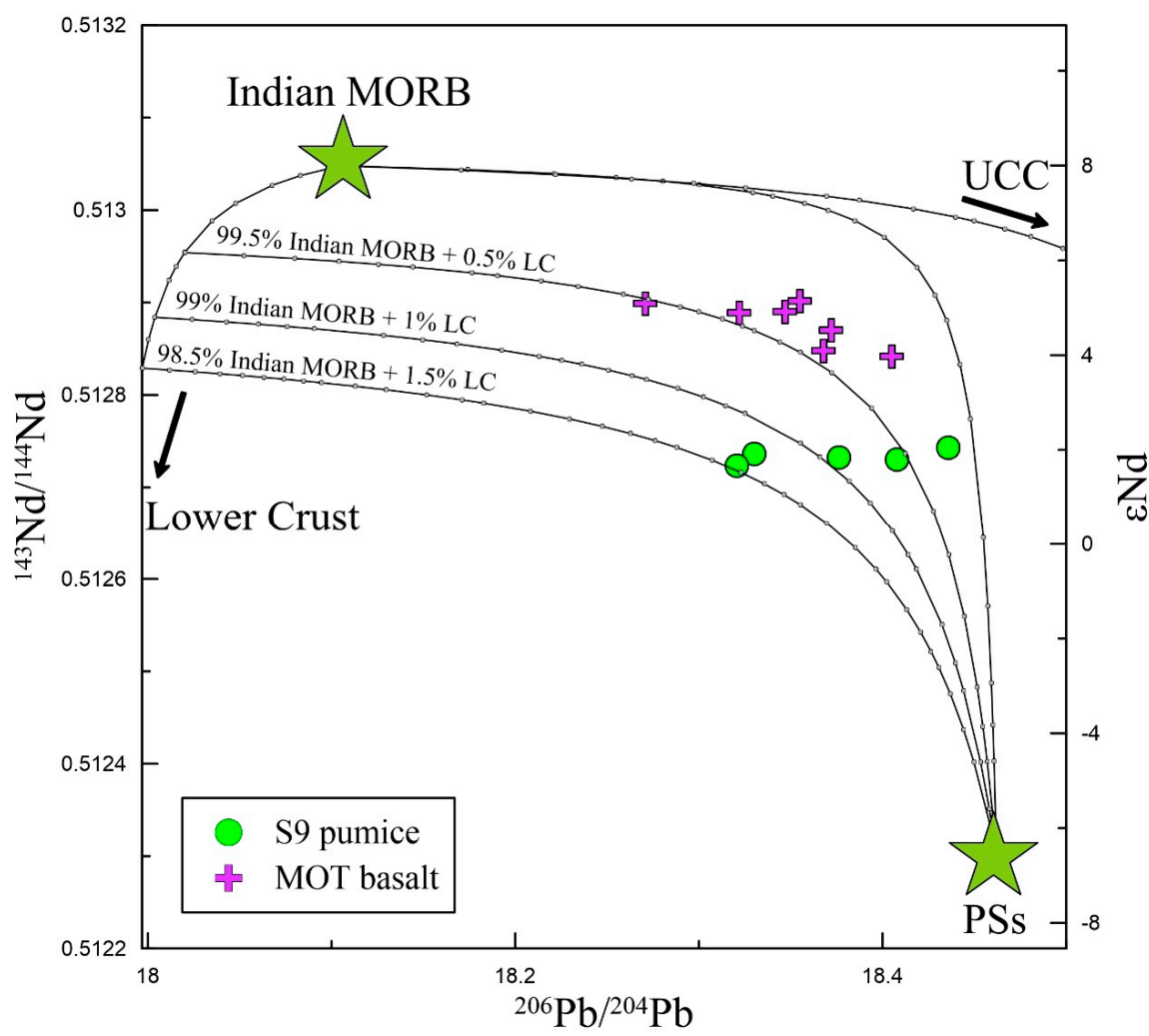

Figure 10. Calculation diagram of ${ }^{143} \mathrm{Nd} /{ }^{144} \mathrm{Nd}$ versus ${ }^{206} \mathrm{~Pb} /{ }^{204} \mathrm{~Pb}$ for S9 pumice and volcanic rocks from the MOT. The endmembers used for calculations in this figure are the same as in Figure 9. The source data of basalts in the MOT are the same as in Figure 6. UCC = upper continental crust; PSs = Philippine Sea sediments; $\mathrm{LC}=$ lower crust.

Table 4. Endmember compositions used in isotopic modeling.

\begin{tabular}{ccccc}
\hline Elements & Indian MORB $^{\mathbf{a}}$ & UCC $^{\mathbf{b}}$ & LC $^{\mathbf{c}}$ & PSs $^{\mathbf{d}}$ \\
\hline $\mathrm{Sr}(\mu \mathrm{g} / \mathrm{g})$ & 7.664 & 333 & 250 & 177.222 \\
$\mathrm{Nd}(\mu \mathrm{g} / \mathrm{g})$ & 0.581 & 27 & 19.5 & 33.423 \\
$\mathrm{~Pb}(\mu \mathrm{g} / \mathrm{g})$ & 0.018 & 25.46 & 7.55 & 43.545 \\
${ }^{87} \mathrm{Sr} / 86 \mathrm{Sr}$ & 0.702987 & 0.72045 & 0.70625 & 0.7122 \\
$143 \mathrm{Nd} /{ }^{144} \mathrm{Nd}$ & 0.513048 & 0.511999 & 0.5124 & 0.5123 \\
${ }^{206} \mathrm{~Pb} / 204 \mathrm{~Pb}$ & 18.1047 & 18.637 & 17.98 & 18.462 \\
\hline
\end{tabular}

${ }^{\text {a }} \mathrm{Sr}-\mathrm{Nd}-\mathrm{Pb}$ isotope data are average composition of Indian Ocean MORB from the PetDB database (http://www. earthchem.org/petdb). Trace element concentrations are from Workman and Hart [74] and Sun and McDonough [54].

${ }^{b}$ The composition of UCC is cited from Meng et al. [81], Zhang et al. [82], and Wedepohl [83]. ${ }^{\mathrm{c}} \mathrm{LC}=$ lower crust, $\mathrm{Sr}-\mathrm{Nd}$ isotope data are from references $[77,78]$. Pb isotope composition is from references $[77,78,84] .{ }^{\mathrm{d}}$ Philippine Sea sediment (PSs) is a composition of sediment at DSDP Sites 442/443/444. Trace and isotope compositions are from Shu et al. [57] and Mahoney [60].

To constrain the magmatic compositions of S9 pumice samples in this study, ${ }^{87} \mathrm{Sr} /{ }^{86} \mathrm{Sr},{ }^{143} \mathrm{Nd} /{ }^{144} \mathrm{Nd}$, and ${ }^{206} \mathrm{~Pb} /{ }^{204} \mathrm{~Pb}$ of the pumices, as well as potential sources, the Indian Ocean MORB-type mantle, the Philippine Sea sediments, lower crustal component, and UCC, together with previously reported volcanic rocks from the MOT were plotted against each other (Figures 9 and 10). S9 pumice samples mainly fall along the mixing line between the Indian Ocean MORB-type mantle and the Philippine Sea sediments, and tend to have a trend towards the mixing line between the Indian Ocean MORB-type mantle and lower crustal component $[77,78,84]$, but far away from the mixing line between the Indian Ocean MORB-type mantle and the UCC (Figure 9). These results suggest that the magmatic composition of S9 pumice is a two-endmembers mixture of the Indian Ocean MORB-type mantle and the Philippine Sea sediments. The UCC did not appear to have significant influence on the magmatic composition 
of S9 pumice samples. In addition, it might be assumed that the parent magma for S9 pumice was slightly contaminated by a lower crustal component, which is relatively evident in the ${ }^{143} \mathrm{Nd} /{ }^{144} \mathrm{Nd}$ versus ${ }^{206} \mathrm{~Pb} /{ }^{204} \mathrm{~Pb}$ diagram (Figure 10 ).

The ${ }^{143} \mathrm{Nd} /{ }^{144} \mathrm{Nd}$ versus ${ }^{206} \mathrm{~Pb} /{ }^{204} \mathrm{~Pb}$ diagram was further employed to evaluate the contribution of lower crustal component on the magmatic composition of S9 pumice (Figure 10). The mixture of Indian Ocean MORB-type mantle and Philippine Sea sediments was inadequate to explain the $\mathrm{Pb}$ isotope composition of magma that $\mathrm{S} 9$ pumice derived from. Lower crustal component is considered to be an endmember for calculation, as expected, the magmatic compositions of S9 pumice may originate from the mixture of Indian Ocean MORB-type mantle, subducted Philippine Sea sediments, and lower crustal component. In addition, we found that the $\mathrm{Sr}-\mathrm{Nd}-\mathrm{Pb}$ isotope composition of $\mathrm{S} 9$ pumice samples, which were erupted in different periods (12.96 cal. ka BP to 11.22 cal. ka BP), displaying no temporal variation trend and varying in narrow ranges (Tables 1 and 3). According to the above discussion, we infer that $\mathrm{S} 9$ pumice was generated from a hybrid magma that was mainly composed of primitive mantle-derived magma with slight assimilation of a lower crustal source, while the primitive mantle-derived magma was originated from Indian Ocean MORB-type mantle metasomatized by subducted Philippine Sea sediments. The magma sources of S9 pumice clasts have remained relatively stable during the eruption history.

To investigate the magma evolution process of the S9 pumice samples, quantitative modeling of fractional crystallization based on major element contents are carried out according to Rayleigh fractionation calculations using constraints of least-squares modeling (Supplementary Table S1). Shinjo and Kato [26] proposed that the observed REE patterns of andesite, dacite, and rhyolite can be reproduced using a three-step fractional crystallization model (i.e., basalt-andesite-dacite-rhyolite), suggesting that dacite can be produced through a two-step fractional crystallization of the associated basalt. According to previous studies $[17,26,27]$, the basalt and andesite in the MOT tend to have similar Sr-Nd isotope compositions (Figure 8), indicating that the S9 pumice samples might be slightly contaminated by the lower crustal material when the magma evolved from andesite to dacite. Therefore, we mainly focus on the fractional crystallization from andesite to dacite (i.e., S9 pumice) in this study. We used the mixed andesite (i.e., $99.5-98.5 \% 287-2 \mathrm{~A}+0.5-1.5 \%$ lower crust; $287-2 \mathrm{~A}$ from Shinjo and Kato [26]) to calculate the REE compositions of S9 pumice samples (Table 5; Figure 11). Because $S 9$ pumice samples have similar geochemical compositions, their normalized formulas of the crystalline phases are nearly consistent. Approximately $50 \%$ fractionation of plagioclase, clinopyroxene, amphibole, magnetite, and apatite can account for the compositional variation from the mixed andesite to S9 pumice clasts. Therefore, we infer that the fractional crystallization of associated basalt can generate the observed compositions of S9 pumice clasts.

Table 5. Partition coefficients ( $\mathrm{K}_{\mathrm{d}}$ values) used in modeling.

\begin{tabular}{ccccccc}
\hline Element & Pl & Opx & Amph & Mt & Ap & Bulk D \\
\hline $\mathrm{La}$ & 0.19 & 0.031 & 1 & 1.5 & 14.5 & 0.707 \\
$\mathrm{Ce}$ & 0.111 & 0.028 & 0.899 & 1.3 & 21.1 & 0.697 \\
$\mathrm{Nd}$ & 0.09 & 0.47 & 1.6 & 1 & 32.8 & 1.054 \\
$\mathrm{Sm}$ & 0.067 & 0.28 & 2 & 1 & 46 & 1.318 \\
$\mathrm{Eu}$ & 0.376 & 0.34 & 3.2 & 0.6 & 30.4 & 1.627 \\
$\mathrm{Gd}$ & 0.063 & 0.039 & 1.72 & 0.3 & 43.9 & 1.12 \\
$\mathrm{Dy}$ & 0.055 & 0.076 & 1.611 & 1 & 50.7 & 1.223 \\
$\mathrm{Er}$ & 0.063 & 0.153 & 1.496 & 1 & 37.2 & 1.036 \\
$\mathrm{Yb}$ & 0.057 & 0.254 & 2.1 & 1 & 15.4 & 0.966 \\
$\mathrm{Lu}$ & 0.056 & 0.71 & 2.1 & 1 & 13.8 & 0.981 \\
\hline
\end{tabular}




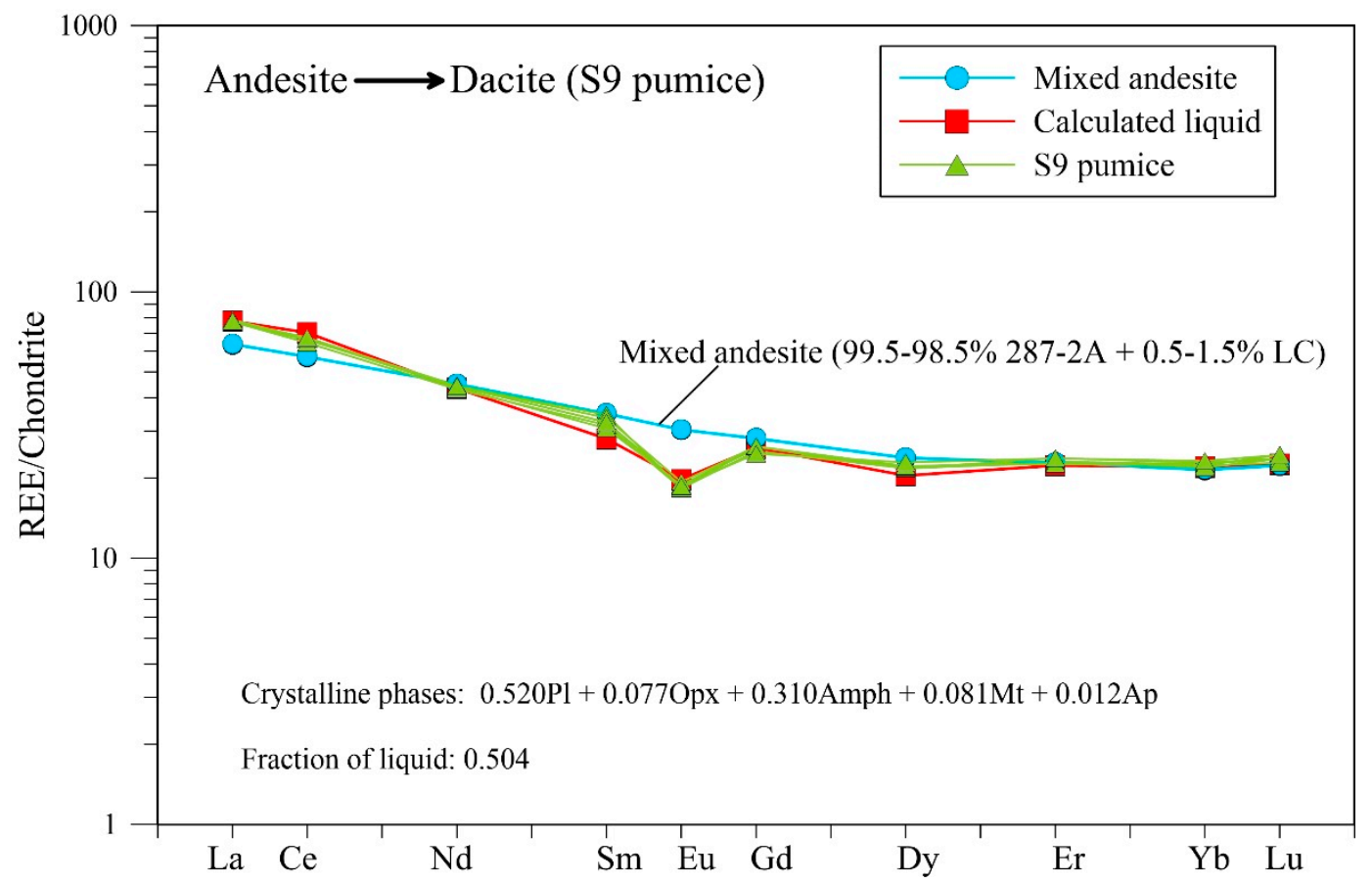

Figure 11. REE patterns of liquids modeled by Rayleigh fractional crystallization from mixed andesite to dacite. The detailed calculation process is shown in Supplementary Table S1. The $\mathrm{K}_{\mathrm{d}}$ values used in modeling are shown in Table 5. $\mathrm{Pl}=$ plagioclase, $\mathrm{Opx}=$ orthopyroxene, $\mathrm{Amph}=$ amphibole, $\mathrm{Mt}=$ magnetite, and Ap = apatite. $\mathrm{LC}=$ lower crust.

The values of distribution coefficients are from: Luhr and Carmichael [85], Fujimaki [86], Bacon and Druitt [87], Schnetzler and Philpotts [88], and Shinjo and Kato [26]. Pl = plagioclase, Opx = orthopyroxene, $\mathrm{Amph}=$ amphibole, $\mathrm{Mt}=$ magnetite, and $\mathrm{Ap}=$ apatite.

Thus, a two-stage genetic model, which includes the mixing primary magmas and significant fractional crystallization, is our preferred interpretation for the origin of S9 pumice. Firstly, the mantle wedge (i.e., Indian Ocean MORB-type mantle) was metasomatized by subducted Philippine Sea sediments to form the primitive magma. Then this primitive magma rose into the lower crust and assimilated by a small amount of lower crustal component in the magma chamber, followed by extensive fractional crystallization to generate the parent magma. On the basis of our radiocarbon dating data, we conclude that core S9 records felsic volcanic activity in the MOT, which occurred during 12.96-11.22 cal. ka BP.

\subsection{Implications for the Existence of a Millennial-Scale Magma Chamber}

The existence of a magma chamber is generally confirmed by geophysical characteristics (e.g., seismic tomography and thermal considerations) [89-91] or large-volume volcanic eruptions [92,93]. The variations in geochemical and mineralogical compositions of volcanic rocks from the OT suggest a complex magmatic system beneath the OT $[20,22,71]$.

Through a comprehensive study of the $\mathrm{Sr}, \mathrm{Nd}$, and $\mathrm{Pb}$ isotope and trace element compositions of $\mathrm{S} 9$ pumice samples, we infer that a magma chamber existed in the lower crust of the MOT. This hypothesis can be supported by many evidence. In this study, the felsic magma was erupted from 12.96 to $11.22 \mathrm{cal}$. $\mathrm{ka} \mathrm{BP}$ and lasted for at least $1.74 \mathrm{ka}$. The felsic pumice studied by Chen et al. [30] and Huang et al. [25] from the MOT erupted in $12.66 \mathrm{cal}$. ka BP and $17.7 \mathrm{cal}$. ka BP. This indicate that felsic volcanic activities were widespread in the MOT during the late Pleistocene and early Holocene. The similarities (small variations) in the trace element abundances, REE patterns, and $\mathrm{Sr}-\mathrm{Nd}-\mathrm{Pb}$ isotope compositions (Table 1) among these pumice samples in S9 suggest the existence of a long-term, relatively stable and convecting magma chamber for continuous supply of magma during this period. Geochemical studies 
by Guo et al. [19] and Zhang et al. [23] inferred that the white pumice magma chamber was probably located in the lower crust, and mineralogical study by Zhai et al. [9] implied that the crystallization of plagioclase and pyroxene occurred approximately $30 \mathrm{~km}$ below the seafloor. Therefore, we infer that the location of magma chamber of the felsic pumice in S9 is in the lower crust, even near the Moho. The Indian Ocean MORB-type mantle and a small amount of lower crustal component and subducted Philippine Sea sediments were mixed, assimilated and homogenized within a shallow magma chamber with a homogeneous isotopic signature (Table 1). Then the magma would further crystallize and fractionate into dacitic magma, after that the melt moved upward and finally erupted from the seafloor. This study supports the existence of a magma chamber beneath the MOT, which played an important role in the creation of the large volumes of silicic magma with nearly identical isotopic compositions from 12.96 to $11.22 \mathrm{cal}$. ka BP.

\section{Conclusions}

In this study, we presented new major and trace element concentrations and $\mathrm{Sr}, \mathrm{Nd}$, and $\mathrm{Pb}$ isotope data, as well as eruption ages for pumice samples recovered from sediment core $\mathrm{S} 9$ from the MOT. The geochemical compositions of S9 pumice samples erupted during 12.96 and $11.22 \mathrm{cal}$. ka BP display no temporal variation trend and vary in narrow ranges. All pumice clasts are dacite, showing characteristics of subduction-related magma and recording relatively higher $\mathrm{Sr}\left({ }^{87} \mathrm{Sr} /{ }^{86} \mathrm{Sr}=\right.$ $0.70480-0.70502)$ and $\mathrm{Pb}\left({ }^{206} \mathrm{~Pb} /{ }^{204} \mathrm{~Pb}=18.321-18.436,{ }^{207} \mathrm{~Pb} /{ }^{204} \mathrm{~Pb}=15.622-15.624\right.$, and ${ }^{208} \mathrm{~Pb} /{ }^{204} \mathrm{~Pb}=$ $38.52-38.63)$ and lower $\mathrm{Nd}\left({ }^{143} \mathrm{Nd} /{ }^{144} \mathrm{Nd}=0.51272-0.51274\right)$ isotope compositions than basalts from the MOT. The parent magma of S9 pumice was most likely generated from a hybrid magma through an extensive fractional crystallization process. The hybrid magma was mainly formed from the mantle-derived magma (i.e., Indian Ocean MORB-type mantle metasomatized by subducted Philippine Sea sediments) assimilated by a small amount of lower crustal component. The data suggest that a magma chamber existed in the lower crust of the MOT during 11.22-12.96 cal. ka BP and supplied felsic magma for at least $1.74 \mathrm{ka}$.

Supplementary Materials: The following are available online at http://www.mdpi.com/2077-1312/7/12/462/s1, Supplementary Table S1 shows the results of the Rayleigh fractionation calculations based on the constraints of least-squares.

Author Contributions: Formal analysis, X.F. and Z.Z.; Funding acquisition, Z.Z.; Investigation, X.F., Z.Z., and S.H.; Methodology, X.F. and X.L.; Resources, Z.Z.; Supervision, Z.Z., S.H., X.L., Z.C., and S.C.; Validation, S.H. and B.Z.; Writing-original draft, X.F.; Writing-review \& editing, X.F., Z.Z., S.H., X.L., and Z.C.

Funding: This research was funded by the National Programme on Global Change and Air-Sea interaction (Grant No. GASI-GEOGE-02). International Partnership Program of Chinese Academy of Sciences (Grant No. 133137KYSB20170003). National Special Fund for the 13th Five Year Plan of COMRA (Grant No. DYI35-G2-01-02), Special Fund for the Taishan Scholar Program of Shandong Province (Grant No. ts201511061), National Basic Research Program of China (Grant No. 2013CB429700), National Natural Science Foundation of China (Grant Nos. 91958213 and 41325021), AoShan Talents Program Supported by Qingdao National Laboratory for Marine Science and Technology (Grant No. 2015ASTP-0S17), Innovative Talent Promotion Program (Grant No.2012RA2191), Scientific and Technological Innovation Project Financially Supported by Qingdao National Laboratory for Marine Science and Technology (Grant Nos.2015ASKJ03 and 2016ASKJ13).

Acknowledgments: The author thank the three anonymous reviewers for their constructive comments.

Conflicts of Interest: The authors declare no conflict of interest.

\section{References}

1. Bourdon, B.; Sims, K.W.W. U-series Constraints on Intraplate Basaltic Magmatism. Rev. Miner. Geochem. 2003, 52, 215-254. [CrossRef]

2. McCulloch, M.; Gamble, J.; McCulloch, M. Geochemical and geodynamical constraints on subduction zone magmatism. Earth Planet. Sci. Lett. 1991, 102, 358-374. [CrossRef]

3. Kessel, R.; Schmidt, M.W.; Ulmer, P.; Pettke, T. Trace element signature of subduction-zone fluids, melts and supercritical liquids at 120-180 km depth. Nature 2005, 437, 724-727. [CrossRef] 
4. Woodhead, J.; Eggins, S.; Gamble, J. High field strength and transition element systematics in island arc and back-arc basin basalts: Evidence for multi-phase melt extraction and a depleted mantle wedge. Earth Planet. Sci. Lett. 1993, 114, 491-504. [CrossRef]

5. Kastens, K.; Mascle, J.; Auroux, C.; Bonatti, E.; Broglia, C.; Channell, J.; Curzi, P.; Emeis, K.-C.; Glaçon, G.; Hasegawa, S.; et al. ODP Leg 107 in the Tyrrhenian Sea: Insights into passive margin and back-arc basin evolution. GSA Bull. 1988, 100, 1140-1156. [CrossRef]

6. Sdrolias, M.; Müller, R.D. Controls on back-arc basin formation. Geochem. Geophys. Geosyst. 2013, 7, Q04016. [CrossRef]

7. Ishikawa, M.; Sato, H.; Furukawa, M.; Kimura, M.; Shimamura, K. Report on DELP 1988 Cruises in the Okinawa Trough: Part 6. Petrology of Volcanic Rocks. Bull. Earthq. Res. Inst. Univ. Tokyo 1991, 66, $151-177$.

8. Sibuet, J.-C.; Hsu, S.-K.; Thareau, N.; Le Formal, J.-P.; Liu, C.-S.; Sibuet, J.; Deffontaines, B.; Hsu, S.; Le Formal, J.; Liu, C. Okinawa trough backarc basin: Early tectonic and magmatic evolution. J. Geophys. Res. Space Phys. 1998, 103, 30245-30267. [CrossRef]

9. Zhai, S.; Chen, L.; Zhang, H.Q. Magmatism and Seafloor Hydrothermal Activities in the Okinawa Trough; Maritime Press: Beijing, China, 2001.

10. Masaaki, K.; Ichiro, K.; Yuzo, K.; Satoshi, Y.; Ikuo, K.; Hidekazu, T.; Hajimu, K.; Nobuhiro, I.; Hideko, M. Report on DELP 1984 Cruises in the Middle Okinawa Trough: Part V: Topography and Geology of the Central Grabens and Their Vicinity. Bull. Earthq. Res. Inst. Univ. Tokyo 1986, 61, 269-310.

11. Zeng, Z.; Yu, S.; Wang, X.; Fu, Y.; Yin, X.; Zhang, G.; Wang, X.; Chen, S. Geochemical and isotopic characteristics of volcanic rocks from the northern East China Sea shelf margin and the Okinawa Trough. Acta Oceanol. Sin. 2010, 29, 48-61. [CrossRef]

12. Yan, Q.; Shi, X. Petrologic perspectives on tectonic evolution of a nascent basin (Okinawa Trough) behind Ryukyu Arc: A review. Acta Oceanol. Sin. 2014, 33, 1-12. [CrossRef]

13. Arakawa, Y.; Kurosawa, M.; Takahashi, K.; Kobayashi, Y.; Tsukui, M.; Amakawa, H. Sr-Nd isotopic and chemical characteristics of the silicic magma reservoir of the Aira pyroclastic eruption, southern Kyushu, Japan. J. Volcanol. Geotherm. Res. 1998, 80, 179-194. [CrossRef]

14. Qin, Y.S.; Zhai, S.K.; Mao, X.Y. Trace element features and its geological significances of pumices from the Okinawa Trough. Oceanol. Limnol. Sin. 1987, 18, 313-319. (In Chinese)

15. Li, X.; Zeng, Z.; Yang, H.; Yin, X.; Wang, X.; Chen, S.; Ma, Y.; Guo, K. Geochemistry of silicate melt inclusions in middle and southern Okinawa Trough rocks: Implications for petrogenesis and variable subducted sediment component injection. Geol. J. 2018, 54, 1160-1189. [CrossRef]

16. Zhai, S.; Gan, X. Study of basalt from the hydrothermal field of the Okinawa Trough. Oceanol. Limnol. Sin. 1995, 26, 115-123, (In Chinese with English Abstract).

17. Shinjo, R.; Chung, S.-L.; Kato, Y.; Chung, S.; Kimura, M. Geochemical and Sr-Nd isotopic characteristics of volcanic rocks from the Okinawa Trough and Ryukyu Arc: Implications for the evolution of a young, intracontinental back arc basin. J. Geophys. Res. Space Phys. 1999, 104, 10591-10608. [CrossRef]

18. Zhai, S.K. The distribution and mineralogical characteristics of the pumice in the Okinawa Trough. Oceanol. Limnol. Sin. 1986, 17, 504-512.

19. Guo, K.; Shu, Y.; Wang, X.; Liu, Q.; Yin, X.; Chen, S.; Chen, Z.; Zhang, G. Different magma sources and evolutions of white and black pumice from the middle Okinawa Trough: Evidence from major, trace elements and Sr-Nd-Pb isotopes. Geol. J. 2018, 54, 206-220. [CrossRef]

20. Liao, R.; Huang, P.; Hu, N.; Li, A. Petrological characteristics of black and white pumice from the Okinawa Trough: Implications for magmatic evolution. Mar. Sci. 2016, 40, 121-130, (In Chinese with English Abstract).

21. Zhang, Y.X.; Zeng, Z.G.; Yin, X.B.; Qi, H.Y.; Li, H.; Wang, X.Y.; Cheng, S. Experimental study of a pretreatment method for submarine pumice. Mar. Sci. 2017, 41, 64-70, (In Chinese with English Abstract).

22. Zhai, S.; Chen, L.; Wang, Z.; Gan, X.Q. Primary analysis on pumice magmatism model of the Okinawa Trough. Mar. Geol. Quat. Geol. 1997, 17, 59-66.

23. Zhang, Y.; Zeng, Z.; Yin, X.; Qi, H.; Chen, S.; Wang, X.; Shu, Y.; Chen, Z.; Li, S. Petrology and mineralogy of pumice from the Iheya North Knoll, Okinawa Trough: Implications for the differentiation of crystal-poor and volatile-rich melts in the magma chamber. Geol. J. 2017, 53, 2732-2745. [CrossRef]

24. Guo, K.; Zhai, S.; Yu, Z.; Cai, Z.; Zhang, X. Sr-Nd-Pb isotopic geochemistry of phenocrysts in pumice from the central Okinawa Trough. Geol. J. 2016, 51, 368-375. [CrossRef] 
25. Huang, P.; Li, A.; Jiang, H. Geochemical features and their geological implications of volcanic rocks from the northern and middle Okinawa Trough. Acta Petrol. Sin. 2006, 22, 1703-1712.

26. Shinjo, R.; Kato, Y. Geochemical constraints on the origin of bimodal magmatism at the Okinawa Trough, an incipient back-arc basin. Lithos 2000, 54, 117-137. [CrossRef]

27. Hoang, N.; Uto, K. Upper mantle isotopic components beneath the Ryukyu arc system: Evidence for 'back-arc' entrapment of Pacific MORB mantle. Earth Planet. Sci. Lett. 2006, 249, 229-240. [CrossRef]

28. Kizaki, K. Geology and tectonics of the Ryukyu Islands. Tectonophysics 1986, 125, 193-207. [CrossRef]

29. Isozaki, Y.; Nishimura, Y. Fusaki Formation, Jurassic subduction-accretion complex on Ishigaki Island, southern Ryukyus and its geologic implication to Late Mesozoic convergent margin of East Asia. Mem. Geol. Soc. Jpn. 1989, 33, 259-275.

30. Chen, L.; Zhai, S.; Shen, S. The isotopic characteristics and dating of pumice in the Okinawa Trough. Sci. China Ser. B 1993, 23, 324-329. (In Chinese)

31. Li, W.R.; Yang, Z.S.; Wang, Y.J.; Zhang, B.M. The Petrochemical Features of the Volcanic Rocks in Okinawa Trough and Their Geological Significance. Acta Petrol. Sin. 1997, 13, 538-550, (In Chinese with English Abstract).

32. Hu, S.; Zeng, Z.; Yin, X.; Zhu, B.; Fang, X.; Qi, H. Characteristic differences of rare earth elements in the sediment cores from Okinawa Trough and their implications for sediment provenance. Mar. Geol. Quat. Geol. 2019, 39, 69-82.

33. Lee, C.-S.; Shor, G.G., Jr.; Bibee, L.D.; Lu, R.S.; Hilde, T.W.C. Okinawa Trough: Origin of a back-arc basin. Mar. Geol. 1980, 35, 219-241. [CrossRef]

34. Li, N. On tectonic problems of the Okinawa Trough. Chin. J. Oceanol. Limnol. 2001, 19, 255-264.

35. Seno, T.; Stein, S.; Gripp, A.E. A model for the motion of the Philippine Sea Plate consistent with NUVEL-1 and geological data. J. Geophys. Res. Space Phys. 1993, 98, 17941-17948. [CrossRef]

36. Yamano, M.; Uyeda, S.; Foucher, J.-P.; Sibuet, J.-C. Heat flow anomaly in the middle Okinawa Trough. Tectonophysics 1989, 159, 307-318. [CrossRef]

37. Shinjo, R.; Woodhead, J.D.; Hergt, J.M. Geochemical variation within the northern Ryukyu Arc: Magma source compositions and geodynamic implications. Contrib. Miner. Pet. 2000, 140, 263-282. [CrossRef]

38. Honma, H.; Kusakabe, M.; Kagami, H.; Iizumi, S.; Sakai, H.; Kodama, Y.; Kimura, M. Major and trace element chemistry and $\mathrm{D} / \mathrm{H}, 18 \mathrm{O} / 16 \mathrm{O}, 87 \mathrm{Sr} / 86 \mathrm{Sr}$ and $143 \mathrm{Nd} / 144 \mathrm{Nd}$ ratios of rocks from the spreading center of the Okinawa Trough, a marginal back-arc basin. Geochem. J. 1991, 25, 121-136. [CrossRef]

39. Hu, S.; Zeng, Z.; Fang, X.; Qi, H.; Yin, X.; Chen, Z.; Li, X.; Zhu, B. Geochemical Study of Detrital Apatite in Sediment from the Southern Okinawa Trough: New Insights into Sediment Provenance. Minerals 2019, 9 , 619. [CrossRef]

40. Nagumo, S.; Kinoshita, H.; Kasahara, J.; Ouchi, T.; Tokuyama, H.; Asanuma, T.; Koresawa, S.; Akiyoshi, H. Report on DELP 1984 Cruises in the Middle Okinawa Trough: Part II: Seismic Structural Studies. Bull. Earthq. Res. Inst. 1986, 61, 167-202.

41. Jacobsen, S.B.; Wasserburg, G. Sm-Nd isotopic evolution of chondrites. Earth Planet. Sci. Lett. 1980, 50, $139-155$. [CrossRef]

42. Chen, F.; Siebel, W.; Satir, M.; Terzioğlu, M.; Saka, K. Geochronology of the Karadere basement (NW Turkey) and implications for the geological evolution of the Istanbul zone. Int. J. Earth Sci. 2002, 91, 469-481. [CrossRef]

43. Jiang, T.; Zeng, Z.; Nan, Q.; Zheng, X.; Ma, B. The garin size characteristics of the Core S9 sediments in the northern Okinawa Trough and their paleoclimate response since Holocene. Quat. Sci. 2015, 35, 307-318, (In Chinese with English Abstract).

44. Reimer, P.J.; Bard, E.; Bayliss, A.; Beck, J.W.; Blackwell, P.G.; Ramsey, C.B.; Buck, C.E.; Cheng, H.; Edwards, R.L.; Friedrich, M.; et al. IntCal13 and Marine13 Radiocarbon Age Calibration Curves 0-50,000 Years cal BP. Radiocarbon 2013, 55, 1869-1887. [CrossRef]

45. Yoneda, M.; Uno, H.; Shibata, Y.; Suzuki, R.; Kumamoto, Y.; Yoshida, K.; Sasaki, T.; Suzuki, A.; Kawahata, H. Radiocarbon marine reservoir ages in the western Pacific estimated by pre-bomb molluscan shells. Nucl. Instrum. Methods Phys. Res. Sect. B 2007, 259, 432-437. [CrossRef]

46. Blaauw, M.; Christen, J.A. Flexible paleoclimate age-depth models using an autoregressive gamma process. Bayesian Anal. 2011, 6, 457-474.

47. Bas, M.J.L.; Maitre, R.W.L.; Streckeisen, A.; Zanettin, B. A Chemical Classification of Volcanic Rocks Based on the Total Alkali-Silica Diagram. J. Pet. 1986, 27, 745-750. [CrossRef] 
48. Roberts, M.P.; Clemens, J.D. Origin of high-potassium, calc-alkaline, I-type granitoids. Geology 1993, $21,825$. [CrossRef]

49. Tatsumi, Y. Formation of the volcanic front in subduction zones. Geophys. Res. Lett. 1986, 13, 717-720. [CrossRef]

50. Kiminami, K.; Imaoka, T.; Ogura, K.; Kawabata, H.; Ishizuka, H.; Mori, Y. Tectonic implications of Early Miocene OIB magmatism in a near-trench setting: The Outer Zone of SW Japan and the northernmost Ryukyu Islands. J. Asian Earth Sci. 2017, 135, 291-302. [CrossRef]

51. Kimura, J.I.; Nagahashi, Y.; Satoguchi, Y.; Chang, Q. Origins of felsic magmas in Japanese subduction zone: Geochemical characterizations of tephra from caldera-forming eruptions < $5 \mathrm{Ma}$ : Origin of caldera eruptions in Japan. Geochem. Geophys. Geosyst. 2015, 16, 2147-2174.

52. Shinjo, R.; Hasenaka, T.; Fujimaki, H. Petrology of volcanic rocks from the higashi formation in aguni-jima island, central ryukyus. J. Miner. Pet. Econ. Geol. 1990, 85, 282-297. [CrossRef]

53. Shinjo, R.; Kato, Y. Petrography of the Ara-dake formation, Kume-jima island, the Ryukyu islands. J. Miner. Pet. Econ. Geol. 1988, 83, 472-485. [CrossRef]

54. Sun, S.S. McDonough Chemical and isotopic systematics of oceanic basalts: Implications for mantle composition and source processes. Geol. Soc. Lond. Spec. Publ. 1989, 42, 313-345. [CrossRef]

55. Dale, C.; Luguet, A.; MacPherson, C.; Pearson, D.; Hickey-Vargas, R.; Dale, C. Extreme platinum-group element fractionation and variable Os isotope compositions in Philippine Sea Plate basalts: Tracing mantle source heterogeneity. Chem. Geol. 2008, 248, 213-238. [CrossRef]

56. Hickey-Vargas, R. Origin of the Indian Ocean-type isotopic signature in basalts from Philippine Sea plate spreading centers: An assessment of local versus large-scale processes. J. Geophys. Res. Space Phys. 1998, 103, 20963-20979. [CrossRef]

57. Shu, Y.; Nielsen, S.G.; Zeng, Z.; Shinjo, R.; Blusztajn, J.; Wang, X.; Chen, S. Tracing subducted sediment inputs to the Ryukyu arc-Okinawa Trough system: Evidence from thallium isotopes. Geochim. Cosmochim. Acta 2017, 217, 462-491. [CrossRef]

58. Hauff, F.; Hoernle, K.; Schmidt, A. Sr-Nd-Pb composition of Mesozoic Pacific oceanic crust (Site 1149 and 801, ODP Leg 185): Implications for alteration of ocean crust and the input into the Izu-Bonin-Mariana subduction system. Geochem. Geophys. Geosyst. 2003, 4, 1-30. [CrossRef]

59. Plank, T.; Langmuir, C.H. The chemical composition of subducting sediment and its consequences for the crust and mantle. Chem. Geol. 1998, 145, 325-394. [CrossRef]

60. Mahoney, J.B. Nd and Sr isotopic signatures of fine-grained clastic sediments: A case study of western Pacific marginal basins. Sediment. Geol. 2005, 182, 183-199. [CrossRef]

61. Zindler, A.; Hart, S. Chemical Geodynamics. Annu. Rev. Earth Planet. Sci. 1986, 14, 493-571. [CrossRef]

62. Hart, S.R. A large-scale isotope anomaly in the Southern Hemisphere mantle. Nature 1984, 309, $753-757$. [CrossRef]

63. Wang, P.J.; Liu, W.Z.; Wang, S.X.; Song, W.H. 40 Ar/39 Ar and K/Ar dating on the volcanic rocks in the Songliao basin, NE China: Constraints on stratigraphy and basin dynamics. Int. J. Earth Sci. 2002, 91, 331-340. [CrossRef]

64. Guillou, H.; Garcia, M.O.; Turpin, L. Unspiked K-Ar dating of young volcanic rocks from Loihi and Pitcairn hot spot seamounts. J. Volcanol. Geotherm. Res. 1997, 78, 239-249. [CrossRef]

65. Condomines, M. Dating recent volcanic rocks through 230Th-238U disequilibrium in accessory minerals: Example of the Puy de Dôme (French Massif Central). Geology 1997, 25, 375. [CrossRef]

66. Gillot, P.-Y.; Cornette, Y. The Cassignol technique for potassium-Argon dating, precision and accuracy: Examples from the Late Pleistocene to Recent volcanics from southern Italy. Chem. Geol. Isot. Geosci. Sect. 1986, 59, 205-222. [CrossRef]

67. Vella, D.; Huppert, H.E. The waterlogging of floating objects. J. Fluid Mech. 2007, 585, 245. [CrossRef]

68. Whitham, A.G.; Sparks, R.S.J. Pumice. Bull. Volcanol. 1986, 48, 209-223. [CrossRef]

69. Allen, S.; Fiske, R.; Cashman, K. Quenching of steam-charged pumice: Implications for submarine pyroclastic volcanism. Earth Planet. Sci. Lett. 2008, 274, 40-49. [CrossRef]

70. Blaauw, M.; Heuvelink, G.B.; Mauquoy, D.; Van Der Plicht, J.; Van Geel, B. A numerical approach to 14C wiggle-match dating of organic deposits: Best fits and confidence intervals. Quat. Sci. Rev. 2003, 22, 1485-1500. [CrossRef] 
71. Chen, Z.; Zeng, Z.; Yin, X.; Wang, X.; Li, X. Petrogenesis of highly fractionated rhyolites in the southwestern Okinawa Trough: Constraints from whole-rock geochemistry data and $\mathrm{Sr}-\mathrm{Nd}-\mathrm{Pb}-\mathrm{O}$ isotopes. Geol. J. 2019, 54, 316-332. [CrossRef]

72. Letouzey, J.; Kimura, M. Okinawa Trough genesis: Structure and evolution of a backarc basin developed in a continent. Mar. Pet. Geol. 1985, 2, 111-130. [CrossRef]

73. Chung, S.-L.; Jahn, B.-M.; Chen, S.-J.; Lee, T.; Chen, C.-H. Miocene basalts in northwestern Taiwan: Evidence for EM-type mantle sources in the continental lithosphere. Geochim. Cosmochim. Acta 1995, 59, 549-555. [CrossRef]

74. Workman, R.K.; Hart, S.R. Major and trace element composition of the depleted MORB mantle (DMM). Earth Planet. Sci. Lett. 2005, 231, 53-72. [CrossRef]

75. Gao, S.; Rudnick, R.L.; Yuan, H.-L.; Liu, X.-M.; Liu, Y.-S.; Xu, W.-L.; Ling, W.-L.; Ayers, J.; Wang, X.-C.; Wang, Q.-H. Recycling lower continental crust in the North China craton. Nature 2004, 432, 892-897. [CrossRef]

76. Hou, Z.; Zheng, Y.; Yang, Z.; Rui, Z.; Zhao, Z.; Jiang, S.; Qu, X.; Sun, Q. Contribution of mantle components within juvenile lower-crust to collisional zone porphyry Cu systems in Tibet. Miner. Depos. 2013, 48, 173-192. [CrossRef]

77. Hosono, T.; Nakano, T.; Shin, K.; Murakami, H. Assimilation of lower to middle crust by high alumina basalt magma as an explanation for the origin of medium-K volcanic rocks in southern Kyushu, Japan. Lithos 2008, 105, 51-62. [CrossRef]

78. Hosono, T.; Nakano, T.; Murakami, H. Sr-Nd-Pb isotopic compositions of volcanic rocks around the Hishikari gold deposit, southwest Japan: Implications for the contribution of a felsic lower crust. Chem. Geol. 2003, 201, 19-36. [CrossRef]

79. Kimura, M. Formation of Okinawa Trough grabens. Mem. Geol. Soc. Jpn. 1983, 22, 141-157.

80. Nash, D.F. The geological development of the north Okinawa Trough area from Neogene time to recent. J. Jpn. Assoc. Pet. Technol. 1979, 44, 109-119. [CrossRef]

81. Meng, X.; Du, D.; Wu, J.; Long, J. Sr, Nd isotope geochemistry of volcanic rocks and its geological significance in the Middle Okinawa Trough. Sci. China D Ser. 1999, 29, 367-371. (In Chinese) [CrossRef]

82. Zhang, B.T.; Chen, P.R.; Ling, H.F. Geochemistry and petrogenesis of the middle Jurassic rhyolite, southern Jiangxi: Trace element and $\mathrm{Pb}-\mathrm{Nd}-\mathrm{Sr}$ isotope geochemical constraints on the upper crustal origin. Acta Petrol. Sin. 2004, 20, 511-520.

83. Wedepohl, K.H. The composion of the continental crust. Geochim. Cosmochim. Acta 1995, 59, 1217-1232. [CrossRef]

84. Tatsumoto, M.; Basu, A.R.; Wankang, H.; Junwen, W.; Guanghong, X. Sr, Nd, and Pb isotopes of ultramafic xenoliths in volcanic rocks of Eastern China: Enriched components EMI and EMII in subcontinental lithosphere. Earth Planet. Sci. Lett. 1992, 113, 107-128. [CrossRef]

85. Luhr, J.F.; Carmichael, I.S.E. The Colima Volcanic complex, Mexico. Contrib. Miner. Pet. 1980, 71, $343-372$. [CrossRef]

86. Fujimaki, H. Partition coefficients of $\mathrm{Hf}, \mathrm{Zr}$, and REE between zircon, apatite, and liquid. Contrib. Miner. Pet. 1986, 94, 42-45. [CrossRef]

87. Bacon, C.R.; Druitt, T.H. Compositional evolution of the zoned calcalkaline magma chamber of Mount Mazama, Crater Lake, Oregon. Contrib. Miner. Pet. 1988, 98, 224-256. [CrossRef]

88. Philpotts, J.A.; Schnetzler, C. Phenocryst-matrix partition coefficients for K, Rb, Sr and Ba, with applications to anorthosite and basalt genesis. Geochim. Cosmochim. Acta 1970, 34, 307-322. [CrossRef]

89. McCarthy, J.; Mutter, J.C.; Morton, J.L.; Sleep, N.H.; Thompson, G.A. Relic magma chamber structures preserved within the Mesozoic North Atlantic crust? GSA Bull. 1988, 100, 1423-1436. [CrossRef]

90. Detrick, R.S.; Buhl, P.; Vera, E.; Mutter, J.; Orcutt, J.; Madsen, J.; Brocher, T. Multi-channel seismic imaging of a crustal magma chamber along the East Pacific Rise. Nature 1987, 326, 35-41. [CrossRef]

91. Kent, G.M.; Harding, A.J.; Orcutt, J.A. Evidence for a smaller magma chamber beneath the East Pacific Rise at $9^{\circ} 30^{\prime}$ N. Nature 1990, 344, 650-653. [CrossRef]

92. O'Hara, M.J. Geochemical evolution during fractional crystallisation of a periodically refilled magma chamber. Nature 1977, 266, 503-507. [CrossRef]

93. Einarsson, P.; Bilham, R.; Sigmundsson, F. Magma chamber deflation recorded by the global positioning system: The Hekla 1991 Eruption. Geophys. Res. Lett. 1992, 19, 1483-1486.

(C) 2019 by the authors. Licensee MDPI, Basel, Switzerland. This article is an open access article distributed under the terms and conditions of the Creative Commons Attribution (CC BY) license (http://creativecommons.org/licenses/by/4.0/). 